\title{
Synoptic- and Meso- $a$-Scale Variations of the Baiu Front Simulated in an AGCM
}

\section{Kozo NINOMIYA, Takeshi ENOMOTO, Teruyuki NISHIMURA, Tuneaki SUZUKI and Shinji MATSUMURA}

Frontier Research System for Global Change, Yokohama, Japan

(Manuscript received 31 March 2003, in revised form 17 August 2003)

\begin{abstract}
The present paper studies features of the Baiu front and associated precipitation systems simulated in the climatological SST run by an AGCM T106L52 (primitive equation spectral model, the maximum wave-number of 106, with 52 vertical levels) in comparison with the features found in observational studies.

The Baiu front is properly simulated in 1-20 June Y07 (the 7th year after the spin-up integration). In this "Baiu phase", the large-scale circulation systems, such as the upper cold lows and blocking ridge in the northern latitudes, westward extending Pacific subtropical anticyclone, monsoon westerly, and subtropical jet stream, are simultaneously maintained. Under this condition, the synoptic- and meso- $\alpha$ scale variations of the Baiu front are simulated. The southward shift of the front occurs when a synopticscale cyclone develops in association with a westerly trough. When westerly troughs are inactive, weak subsynoptic-scale depression is formed in the frontal zone. A few meso- $\alpha$-scale precipitation systems are generated in the trailing portion of the preceding depression, and form a "Baiu precipitation system family" with a length of $\sim 2000 \mathrm{~km}$. This indicates that the simulation of the realistic Baiu front depends on the maintenance of proper large- and synoptic-scale circulation systems.

However, the Baiu precipitation zone disappears in the early July, as the west-east elongating barotropic anticyclone, which is usually seen over Japan in August in the real atmosphere, is situated over $\sim 37^{\circ} \mathrm{N}$.
\end{abstract}

\section{Introduction}

The summer monsoon rainfalls over East Asia are identified as Meiyu in China, and Baiu in Japan. In the Meiyu-Baiu rainy season, the west to east elongating rain/cloud zone forms with a stationary front, which is called the Meiyu-Baiu front (e.g., Ninomiya and Murakami 1987; Tao and Chen 1987; Ding 1991; Ninomiya and Akiyama 1992). It is known that features of the front over China (Meiyu-front)

Corresponding author: Kozo Ninomiya, Frontier Research System for Global Change, Yokohama 236-0001 Japan.

E-mail: nmiya@jamstec.go.jp

(C) 2003, Meteorological Society of Japan are significantly different from those over the Japan Islands (Baiu front).

Recent progress of the AGCM (atmospheric general circulation model) enables us to make simulation studies of various circulation systems. However, the AGCM simulation study of the Meiyu-Baiu front has not been made in depth. Sugi et al. (1995) noted that representation of the Meiyu-Baiu front is difficult in an AGCM with a low resolution (T42L21; the maximum total wave-number is 42 in triangular wave transformation, and the number of the vertical level is 21). Some experiments with higher resolution (e.g., Kar et al. 1996 by T106L21) also showed insufficient precipitation in the Meiyu-Baiu front.

Yoshikane et al. (2001) studied the formation 
of the Meiyu-Baiu front by a regional model with specified boundary and initial conditions. They concluded that the Meiyu-Baiu front is sustained mainly by the continent-ocean thermal contrast.

Ninomiya et al. (2002) studied features of the Meiyu-Baiu front and associated circulation systems simulated in by T42L52. In their experiment, the Baiu front is not properly reproduced in the monthly averaged field, owing to the alternation of the relatively short "Baiu phase" and the longer "non Baiu phase". In the "Baiu phase", the large-scale circulation systems, such as the upper cold lows and blocking ridge in the northern latitudes, westward extending Pacific Subtropical anticyclone, monsoon westerly, and subtropical jet stream are simultaneously maintained. Under this condition, the Baiu front is reasonably reproduced. By contrast, in the "non Baiu phase", the Baiu front is not formed, since large-scale systems favorable to sustain the Baiu front are not properly reproduced, while the continent-ocean thermal contrast is maintained. Judging from the results, they concluded that the formation of the Baiu front does not depend only on the direct local effects of physical processes and the continent-ocean thermal contrast, but depends on the maintenance of large-scale circulation systems necessary to sustain the Baiu front. To reproduce proper large-scale circulation systems, higher resolution of the model will be needed. Kawatani and Takahashi (2003) reproduced properly the Baiu frontal rain zone for June in the simulation by T106L60.

In these previous AGCM studies, the timeaveraged features have been mainly discussed without attention on individual precipitation systems. Meanwhile, the mesoscale simulation studies of the Baiu precipitation systems have been made for a certain short integration period of 1 or 2 days, with given precise initial condition.

In this study, we demonstrate that the AGCM T106L52 is able to simulate the Baiu front and associated precipitation systems without the specified initial condition.

\section{Model and procedure of simulation}

The model used in this study, a primitive equation spectral model T106L52 (the maximum wave-number is 106 in triangular wave transformation, and the number of the vertical $\sigma$-level is 52) is a high resolution version of CCSR/NIES T42L20 (Numaguchi et al. 1997). Although physical process schemes used in T106L52 are almost the same to these used in T42L20, some tunings are needed when the resolution is increased, to obtain reasonable general circulations. Special tuning for the simulation of the Baiu front is not made.

The thickness of the model layers is $\sim 40 \mathrm{~m}$ in the lower troposphere, but increased gradually to $\sim 600 \mathrm{~m}$ in the lower stratosphere, with the top at $\sim 1 \mathrm{hPa}$. The processes in the planetary boundary layer, which are necessary to produce large-scale circulations, will be simulated reasonably by this vertical resolution. The horizontal resolution of T106, which corresponds to the $\sim 1.1^{\circ}$ Gaussian grid, will simulate circulation systems of horizontal scale larger than $\sim 500 \mathrm{~km}$, which corresponds to the large meso$\alpha$-scale.

The time integration is performed with seasonally varying climatological SST (sea surface temperature). We made a 7-year integration after the spin-up period. The results obtained at a 6-hour interval, in June and July of the 7th year (Y07) integration are used for this study.

\section{Observed features of the Meiyu-Baiu front and associated circulation systems}

Observed basic features of the Meiyu-Baiu front, and associated circulation systems are described first. The latitude-time section of TBB (cloud top equivalent blackbody temperature) obtained from GMS (Geostationary Meteorological Satellite) infrared (IR) observation, along $129.5^{\circ} \mathrm{E}$ meridian for 15 June-5 July 1991 is presented in Fig. 1 as a typical example of observations. The Baiu frontal cloud zone in $30-40^{\circ} \mathrm{N}$ is clearly separated from the ITCZ cloud zone and high-latitude cloud systems. The Baiu cloud zone indicates synopticand meso- $\alpha$-scale variations. For example, the larger cloud systems seen in 16 June and 29 June 1991 are associated with synoptic-scale cyclones. The period in 18-24 June, and in 30 June-5 July 1991 are signified by the successive passage of meso- $\alpha$-scale cloud systems along the west-east elongating Baiu cloud zone.

The west-east elongating stationary Baiu front is not always sustained during the Baiu 
TBB 129.5E

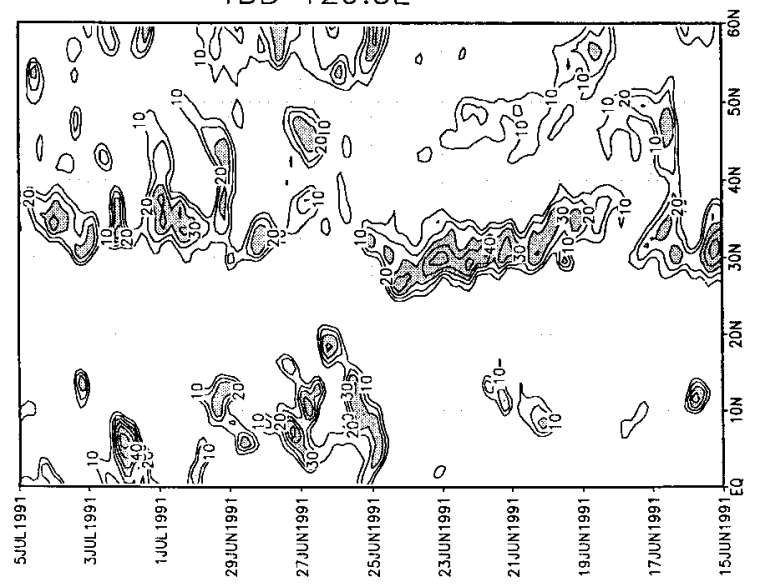

Fig. 1. Latitude-time section of TBB (cloud top equivalent blackbody temperature) along $129.5^{\circ} \mathrm{E}$ for the period between 15 June and 5 July 1991. The isopleths of TBB are given at $10^{\circ} \mathrm{C}$ interval. The minus sign is omitted from the labeled numeral. The shading indicates cloud areas where TBB is colder than $-30^{\circ} \mathrm{C}$.

season. The Baiu frontal cloud zone often indicates the wavy cloud pattern seen in the map of TBB for 12 UTC 16 June 1991 (Fig. 2A). The following general features of the wavy Baiu frontal cloud zone can be deduced by inspecting satellite cloud images and weather maps during the Baiu season:

(1) Weak polar air outbreak from the polar maritime airmass over the Japan Sea, the Okhotsk Sea and the northwestern Pacific takes place, when the synoptic-scale cyclone develops to the east of the Japan Islands.

(2) The Baiu frontal cloud area with the warm and moist airs moves northward ahead of the synoptic-scale cyclone. Then, the Baiu frontal cloud zone shifts southward owing to the weak polar air outbreak, and indicates the wavy pattern of the cloud zone seen in the map of TBB for 12 UTC 16 June 1991 (Fig. 2A).

Discussions on such synoptic-scale variation of the Baiu front simulated in the model will be given in Section 5.

Meanwhile, the west-east elongating cloud zone tends to form in association with weak

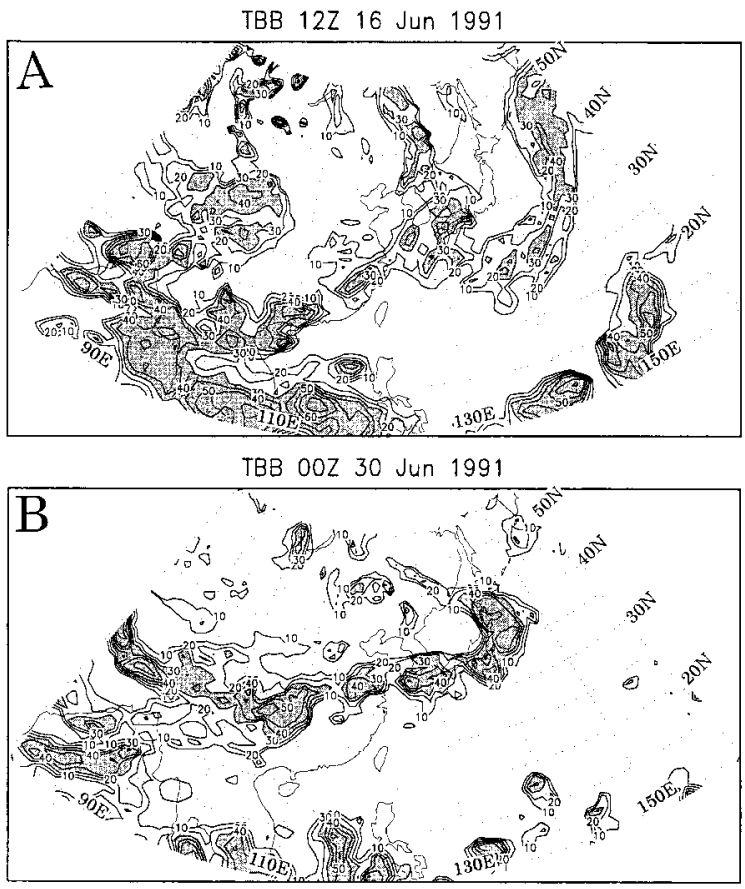

Fig. 2. A: TBB map for 12 UTC 16 June 1991 shows an example of the wavy pattern of Baiu frontal cloud zone. The isopleths of TBB are given at $10^{\circ} \mathrm{C}$ interval. The minus sign is omitted from the labeled numeral. The shading indicates cloud areas where TBB is colder than $-30^{\circ} \mathrm{C}$.

B: TBB map for 12 UTC 30 June 1991 shows an example of west-east elongating Baiu frontal cloud zone. A few meso$\alpha$-scale cloud systems align in the cloud zone.

sub-synoptic-scale depressions. The TBB map for 12 UTC 30 June 1991 (Fig. 2B) shows a typical example of the west-east elongating cloud zone. Since intense precipitation tends to occur in such cloud zone, the west-east elongating cloud zone has been studied in many papers. Although observational studies for the Meiyu-Baiu season of 1968 (Akiyama 1973), 1975 (Ninomiya 1984), 1979 (Ninomiya and Muraki 1986), 1982 (Akiyama 1989, 1990) and 1991 (Ninomiya 2000, 2001; Ninomiya and Shibagaki 2003) indicate significant variations from case to case, the following general features of the west-east elongated cloud/ precipitation zone can be deduced from the papers mentioned above: 
(1) The intense precipitation zone of $\sim 300 \mathrm{~km}$ width extends from the eastern foot of the Tibetan Plateau to the western North Pacific, along $30-35^{\circ} \mathrm{N}$ latitude circle. Precipitation is very small to the north and the south of the precipitation zone.

(2) The confluence/convergence of the Indian monsoon westerly and the Pacific trade wind easterly results in the strong southerly moisture transport along the western rim of the westward extending North $\mathrm{Pa}$ cific subtropical anticyclone.

(3) The Meiyu-Baiu precipitation zone is situated to the south of the subtropical jet stream, and to the north of the Meiyu-Baiu low-level jet stream.

(4) The ascending motion, strong apparent moisture sink and strong apparent heat source are found in the precipitation zone. Nearly moist neutral stratification is maintained in the Baiu precipitation zone, since instability generated by the differential advection is simultaneously released by the convections. Meanwhile moist unstable stratification is sustained in the Meiyu precipitation zone.

(5) The Meiyu front forms along the northern boundary of the moist maritime tropical airmass. The reverse thermal gradient is seen to the north of the frontal zone, between the frontal zone cooled by precipitation and the dry hot continental airmass.

(6) The Baiu front forms between the tropical maritime airmass and the polar maritime airmass.

(7) In the northern latitudes $\left(45-60^{\circ} \mathrm{N}\right)$, a blocking ridge develops around $140^{\circ} \mathrm{E}$ during the active phase of Meiyu-Baiu. Upper cold lows develop to west (over Siberia) and east (over the Aleutian Islands or the western North Pacific) of the blocking ridge.

(8) The Baiu frontal cloud zone consists of a few trains of cloud systems with length of $\sim 2000 \mathrm{~km}$, which is recognized as a "cloud system family". Each family consists of a preceding sub-synoptic-scale cloud system and a few meso- $\alpha$-scale cloud systems aligned along the trailing portion of the sub-synoptic-scale cloud system.

The features of the west-east elongating cloud zone and the cloud system family simu- lated in the model will be analyzed in Sections 6 and 7.

\section{Overall features of precipitation in June of Y07}

During June Y07, the Meiyu-Baiu precipitation zone is reasonably reproduced in 1-20 June. The averaged precipitation for this period is shown in Fig. 3A. A zone of precipitation more than $8 \mathrm{~mm} \mathrm{~d}^{-1}$ extends from $110^{\circ} \mathrm{E}$ to $160^{\circ} \mathrm{E}$ along $\sim 35^{\circ} \mathrm{N}$ latitude circle. The sealevel pressure averaged for this period is presented in Fig. 3B. Large pressure difference is sustained between the low-pressure area over China and the north Pacific subtropical anticyclone. The western tip of subtropical anticyclone protrudes westward to $\sim 20^{\circ} \mathrm{N} / 125^{\circ} \mathrm{E}$. The surface ridge of $\sim 1014 \mathrm{hPa}$ is seen over the northern Okhotsk Sea. In Fig. 3B, "C" and "R" indicate the location of the cold lows and the blocking ridge on the time averaged $500-\mathrm{hPa}$ height field (figure is not presented), respectively. During this period, the jet stream at $200 \mathrm{hPa}$ extends along $\sim 40^{\circ} \mathrm{N}$ latitude circle (figure is not presented). The large-scale circulation systems are reasonably reproduced for this period.

Figure 3C shows averaged latent heat flux simulated for this period. The latent heat flux in the polar marine areas is very small, while the latent heat flux over the subtropical and tropical oceanic areas is large, with a maximum of $\sim 150 \mathrm{~W} \mathrm{~m}^{-2}$ over the ITCZ. Considerably large latent heat flux $\left(75-150 \mathrm{~W} \mathrm{~m}^{-2}\right)$ is simulated over the continent, except for the arid region. The sensible heat flux (map is not presented) is generally small over the oceanic areas, and the wet (rainfall) land areas, while large sensible heat flux $\left(25-75 \mathrm{~W} \mathrm{~m}^{-2}\right)$ is seen over the arid land areas $\left(37-47^{\circ} \mathrm{N}, 90-115^{\circ} \mathrm{E}\right)$. The distribution of sensible heat flux obtained in this simulation is approximately the same as that obtained by T42L52 (Ninomiya et al. 2002).

Figure 4 shows the latitude-time section of simulated precipitation along the $135^{\circ} \mathrm{E}$ and $160^{\circ} \mathrm{E}$ meridian for 5-20 June of Y07. At $135^{\circ} \mathrm{E}$ (Fig. 4A), the northern precipitation zone $\left(\sim 55^{\circ} \mathrm{N}\right)$, Baiu rain zone $\left(\sim 35^{\circ} \mathrm{N}\right)$ and the ITCZ $\left(\sim 10^{\circ} \mathrm{N}\right)$ are clearly separated by the nonprecipitation zones. The Baiu frontal precipitation zone is more clearly simulated, as com- 

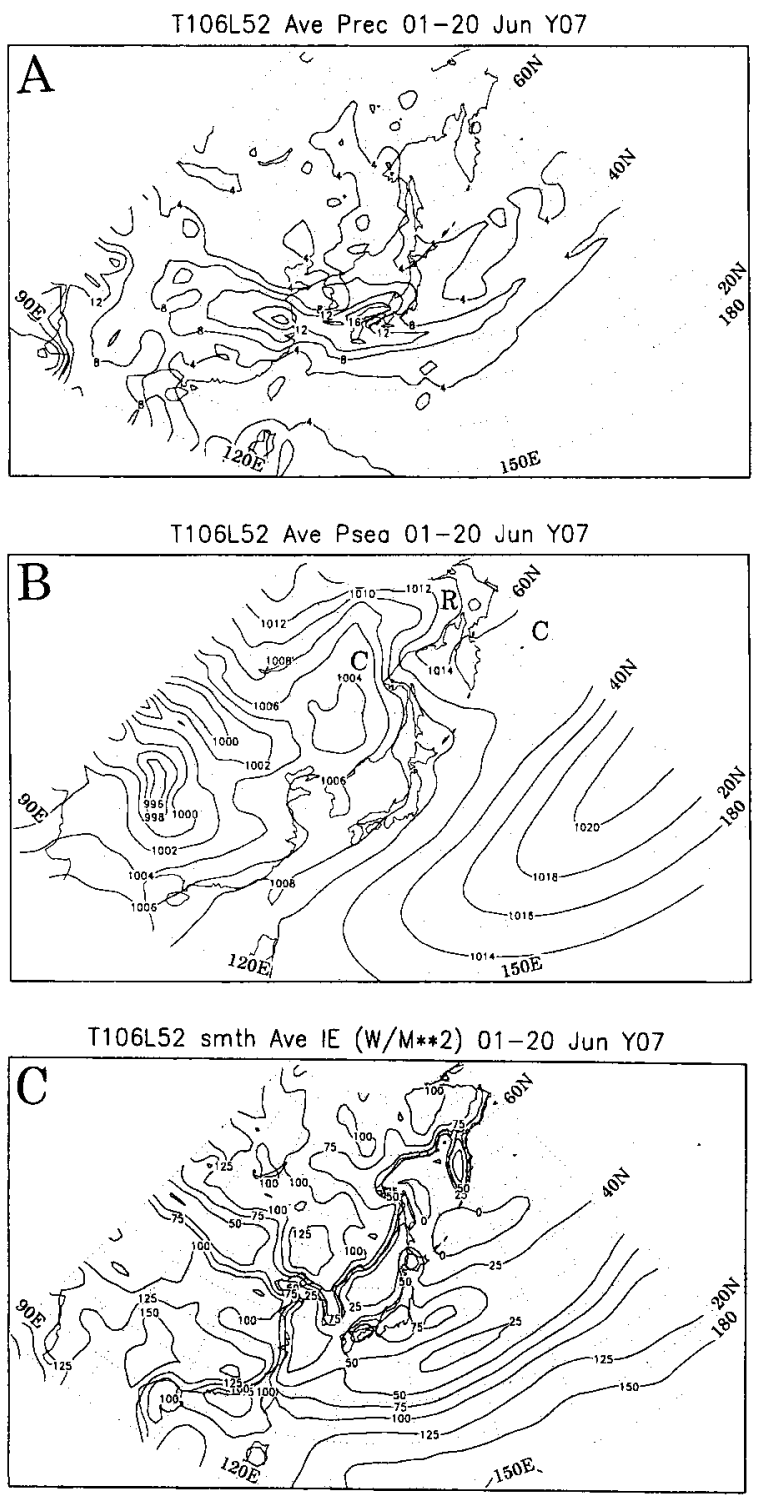

Fig. 3. A: The 20-day averaged simulated precipitation for 1-20 June of Y07. Isopleths are given for 4, 8, 12 and $16 \mathrm{~mm} \mathrm{~d}^{-1}$.

B: The 20-day averaged simulated sea-level pressure for 1-20 June of Y07. Isobars are given at 2 -hPa intervals. In the map, " $C$ " and " $R$ " indicate the location of upper cold lows and blocking ridge at 20-day averaged height field at 500-hPa.

C: The 20-day averaged simulated latent heat flux (unit $\mathrm{W} \mathrm{m} \mathrm{m}^{-2}$ ) for 1-20 June of Y07. The horizontal smoothing is applied for this map. pared with the results by T42L52 (Ninomiya et al. 2002). The precipitation system indicated by "S" is accompanied by a synoptic-scale cyclone. The period between 6 and 9 June is the period of wavy rain zone, which is formed after the passage of the synoptic-scale cyclone (see Section 5). The cloud system labeled by " $D$ " is associated with a weak frontal depression. The rain zone indicated by "Z" is sustained during the period between 9 and 14 June. Three meso$\alpha$-scale precipitation systems are generated successively within the rain zone "Z".

Features of precipitation at $160^{\circ} \mathrm{E}$ (Fig. 4B) are significantly different from these at $135^{\circ} \mathrm{E}$ (Fig. 4A). About this, a brief discussion will be given in Section 7.

\section{The wavy Baiu front simulated in AGCM}

We selected the period of 6-8 June Y07 as an example of the wavy Baiu front. The sea-level pressure simulated for 12 UTC 7 June Y07 (Fig. 5A) shows development of a synoptic-scale cyclone over $\sim 42^{\circ} \mathrm{N} / 148^{\circ} \mathrm{E}$. This development resulted from the merging of the low in $\sim 40^{\circ} \mathrm{N}$ (indicated by - ) with the low in $\sim 30^{\circ} \mathrm{N}$ (indicated by $\bigcirc$ ). The locations of these lows are indicated in Fig. 5A at 24-hour interval. Until 12 UTC 5 June, they are identified as separate lows. They approached and formed a "double center low" over the Japan Island around 12 UTC 6, which developed into a cyclone of $\sim 996 \mathrm{hPa}$ at 12 UTC 7 June. It is reasonable to express the intensity of the cyclone by the pressure depth $\Delta p$, which is the difference between the pressure around the cyclone and the central pressure, not by the central pressure itself. Here, $\Delta p$ is defined by $\Delta p=-N \times 4 \mathrm{hPa}$, where $N$ indicates the number of the closed isobar drawn at $4 \mathrm{hPa}$ intervals. The pressure depth $\Delta p$ of $-16 \mathrm{hPa}$ is seen at 12 UTC 7 June.

The weak polar air outbreak from the polar maritime airmass takes place as northerly winds predominate to the west of the developed cyclone (figure is not shown). At the same time, the significant descending motion occurs over the Japan Islands. The descending velocity at $600 \mathrm{hPa}$ of $\sim 12 \mathrm{hPa} \mathrm{h}^{-1}$ is simulated for this time (figure is not presented). The precipitation rate and specific humidity at $700 \mathrm{hPa}$ simulated for 12 UTC 7 June are presented in Figs. $5 \mathrm{~B}$ and $5 \mathrm{C}$, respectively. In association with the 
A T106L52 PREC 135E 122 04-122 19 JUT Y07

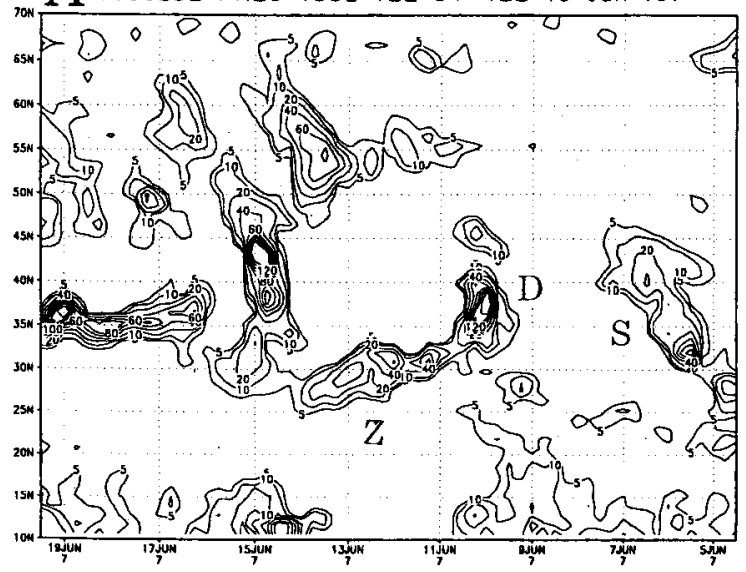

B T106L52 PREC 160E $12 Z$ 04-12Z 19 Jun Y07

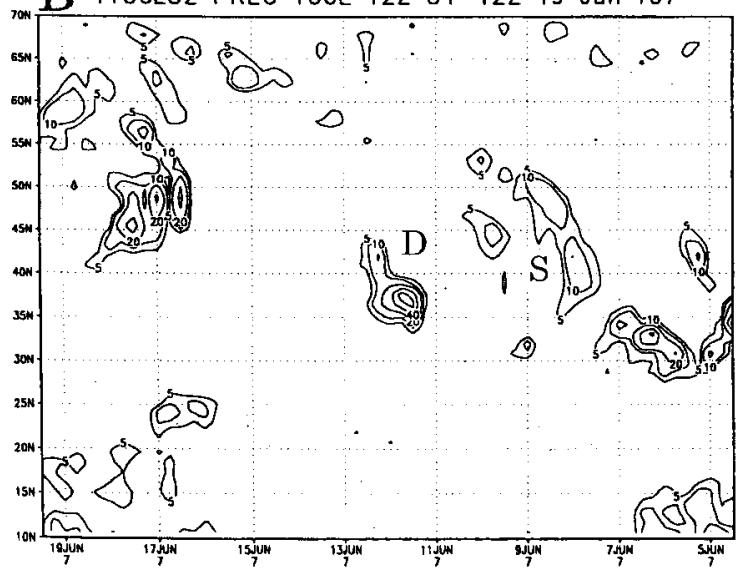

Fig. 4. A: The latitude-time section of the simulated precipitation rate (unit in $\mathrm{mm} \mathrm{d}^{-1}$ ) along $135^{\circ} \mathrm{E}$ for 5-19 June of Y07. Isopleths are given at $20 \mathrm{~mm} \mathrm{~d}^{-1}$ intervals, and for 5 and $10 \mathrm{~mm} \mathrm{~d}^{-1}$. In this figure, " $S$ " and " $D$ " indicate the cloud system associated with the synoptic-scale cyclone and the subsynoptic-scale frontal depression, respectively. "Z" indicates the west-east elongating precipitation zone.

B: The latitude-time section of the simulated precipitation rate (unit in $\mathrm{mm} \mathrm{d}^{-1}$ ) along $160^{\circ} \mathrm{E}$ for 5-19 June of Y07. "S" and "D" indicate the cloud system associated with the synoptic-scale cyclone and the subsynoptic-scale frontal depression, respectively.
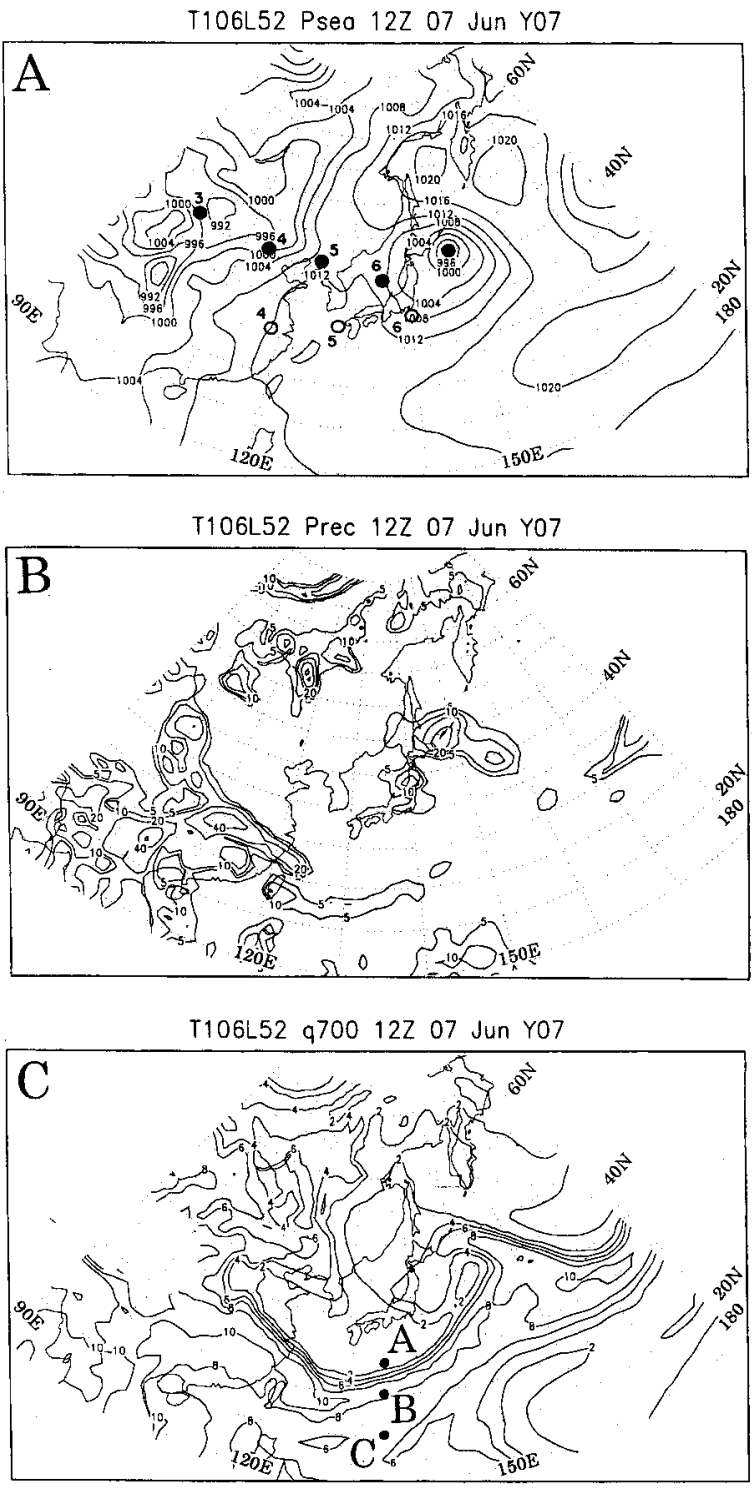

Fig. 5. A: Simulated sea-level pressure for 12 UTC 7 June of Y07. Isobars are given at 4 -hPa intervals. The 24 -hourly location of cyclone in the northern and the southern latitude are indicated by - and $\bigcirc$, respectively. These two cyclones merged and cause the development of an extratropical cyclone to the east of the northern Japan in 7 June of Y07.

B: Simulated precipitation rate for 12 UTC 7 June of Y07. Isopleths are given for $5,10,20,40$ and $60 \mathrm{~mm} \mathrm{~d}^{-1}$.

C: Simulated specific humidity at $700 \mathrm{hPa}$ for 12 UTC 7 June of Y07. Isopleths are given at $2 \mathrm{~g} \mathrm{~kg}^{-1}$ intervals. The vertical profiles of $s / c_{p}, h / c_{p}$ and $h^{*} / c_{p}$ at point A, B and C are presented in Fig. 6. 

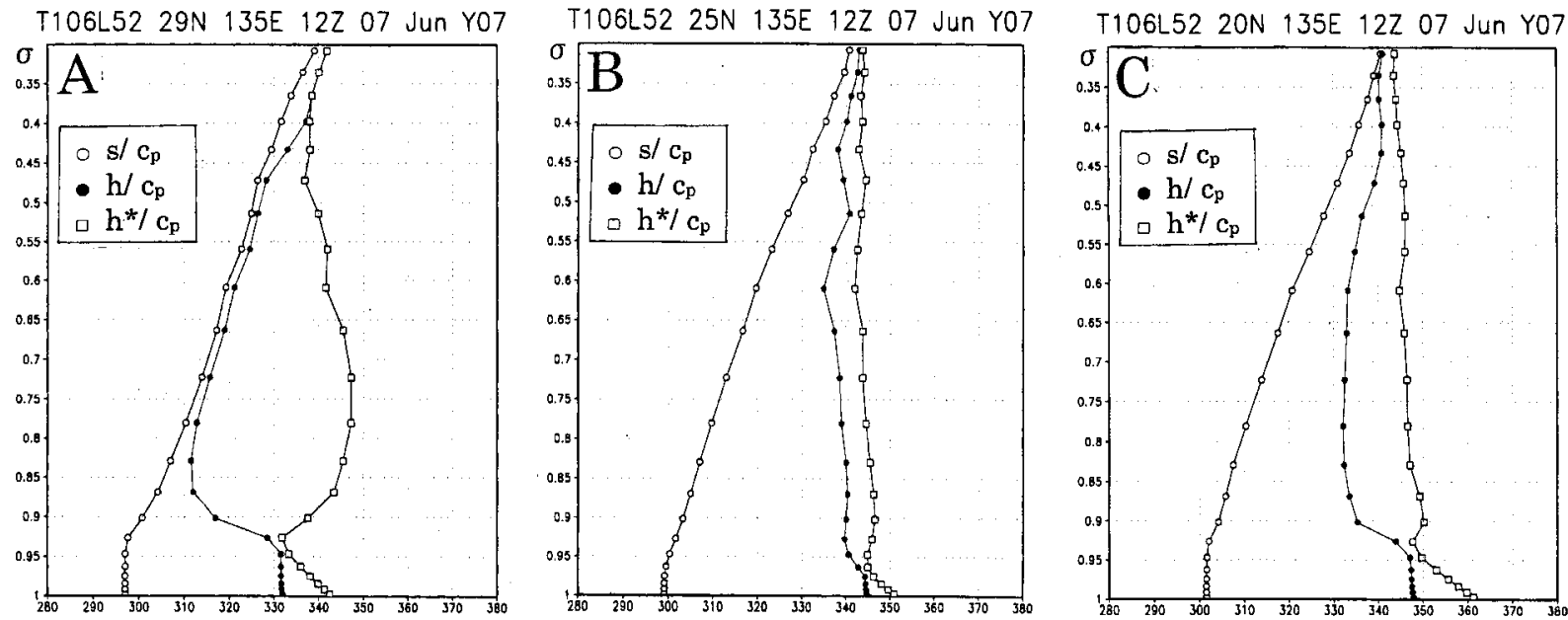

Fig. 6. The vertical profiles of simulated $\left(s / c_{p}\right),\left(h / c_{p}\right)$ and $\left(h^{*} / c_{p}\right)$ at $\sigma$-levels, in unit of K, for 12 UTC 7 June at point $\mathrm{A}\left(29^{\circ} \mathrm{N}, 135^{\circ} \mathrm{E}\right.$; north to the cloud zone $), \mathrm{B}\left(25^{\circ} \mathrm{N}, 135^{\circ} \mathrm{E}\right.$; within the cloud zone) and $\mathrm{C}\left(20^{\circ} \mathrm{N}, 135^{\circ} \mathrm{E}\right.$; south to the cloud zone). The location of point A, B and C are shown in Fig. $5 \mathrm{C}$.

polar air outbreak and the descending motion, the Baiu frontal precipitation zone shifts southward and exhibits the feature of the wavy rain zone. The precipitation rate in the wavy rain zone is $\sim 5 \mathrm{~mm} \mathrm{~d}^{-1}$, at most.

The cyclone deepens further as it moves northeastward. The central pressure drops to $\sim 992 \mathrm{hPa}$ at $12 \mathrm{UTC} 8$ June over $\sim 45^{\circ} \mathrm{N}$ and $150^{\circ} \mathrm{E}$. At this stage, the pressure depth $\Delta p$ reaches $-20 \mathrm{hPa}$. After 9 June, the cyclone weakens gradually. As the cyclone moves northeastward, the moist zone moves further southeastward slowly. The moist zone remains over the subtropical Pacific Ocean for a few days after its formation stage. As described above, the wavy Baiu front is properly simulated by T106L52.

The vertical stratification in and around the moist zone is examined by showing the simulated data at $\sigma$-levels for 12 UTC 07 June Y07. Vertical distribution of $\left(s / c_{p}\right),\left(h / c_{p}\right)$ and $\left(h^{*} / c_{p}\right)$ at selected points (see Fig. 5C for location of the points A, B and C) are presented in Fig. 6, where $s, h, h^{*}$, and $c_{p}$ indicate static energy, moist static energy, saturated moist static energy, and specific heat of the air at constant pressure, respectively.

Data at $29^{\circ} \mathrm{N} / 135^{\circ} \mathrm{E}$ (to the north of the moist zone; Fig. 6A) show stable stratification. The mixed layer is capped by a stable layer in $\sigma$ - level of $0.925-0.85$. The very dry airs above the stable layer are owing to the descending motion. Profiles at $25^{\circ} \mathrm{N} / 135^{\circ} \mathrm{E}$ (within the moist zone; Fig. 6B) indicate the weak convectively unstable stratification. The maximum of $\left(h / c_{p}\right)$ in the lowermost layer slightly exceeds the value of $\left(h^{*} / c_{p}\right)$ in the layer above $\sigma$-level of $\sim 0.85$. Data at $20^{\circ} \mathrm{N} / 135^{\circ} \mathrm{E}$ (south to the moist zone; Fig. 6C) show the mixed layer capped by a stable layer.

\section{The west-east elongating Baiu front}

On the latitude-time section of simulated precipitation along $135^{\circ} \mathrm{E}$ meridian (Fig. 3A), the rain zone " $\mathrm{Z}$ " remains at $\sim 30^{\circ} \mathrm{N}$ during the period between 9 and 13 June. On the map of averaged precipitation for the period between 00 UTC 9 and 00 UTC 13 June (Fig. 7A), a rain zone elongates from $\sim 30^{\circ} \mathrm{N} / 110^{\circ} \mathrm{E}$ to $40^{\circ} \mathrm{N} / 180^{\circ} \mathrm{E}$. Two maximum precipitation areas are seen within the rain zone; one is over $\sim 37^{\circ} \mathrm{N} / 130^{\circ} \mathrm{E}$, and another over $32^{\circ} \mathrm{N} / 135^{\circ} \mathrm{E}$. As shown later, the northern maximum precipitation is brought out by passage of the subsynoptic-scale depression, while the southern maximum is associated with the narrow rain zone. The time averaged sea-level pressure for this period (Fig. 7B) exhibits the typical features of the active Baiu period, which are characterized by the west-east elongating 

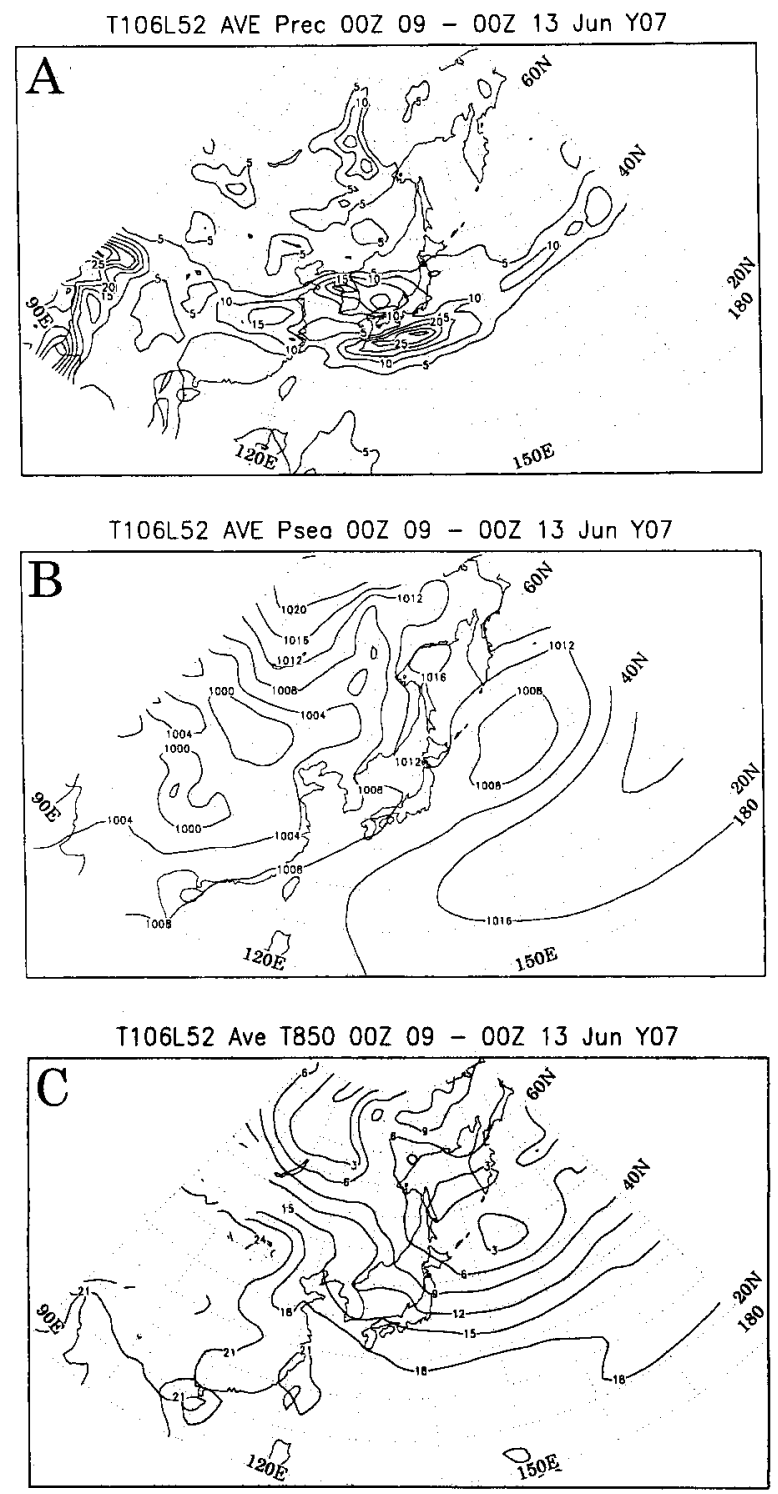

Fig. 7. A: The 5-day averaged simulated precipitation rate for 9-13 June Y07. Isopleths are given at $5 \mathrm{~mm} \mathrm{~d}^{-1}$ intervals.

B: The 5-day averaged simulated sealevel pressure for 9-13 June Y07. Isobars are given at $4-\mathrm{hPa}$ intervals.

$\mathrm{C}$ : The 5-day averaged simulated 850 $\mathrm{hPa}$ temperatures for 9-13 June Y07. The isotherms are given at $3^{\circ} \mathrm{C}$ intervals. trough along the rain zone, the westward protruding Pacific subtropical anticyclone and the ridge over the Okhotsk Sea. The map of time averaged $850-\mathrm{hPa}$ temperature (Fig. $7 \mathrm{C}$ ) indicates that the Meiyu front is not associated with significant thermal gradient, while the Baiu front is associated with strong thermal gradient between the polar maritime airmass and the tropical maritime airmass.

The time averaged wind velocity at $850 \mathrm{hPa}$ (Fig. 8A) shows the Baiu low-level jet stream, along the northern rim of the Pacific subtropical anticyclone. On the map of averaged height field at $700 \mathrm{hPa}$ (Fig. 8B), two cold lows (thermal field is not presented) are located at $\sim 55^{\circ} \mathrm{N} / 130^{\circ} \mathrm{E}$ and $\sim 45^{\circ} \mathrm{N} / 160^{\circ} \mathrm{E}$, while a blocking ridge is seen over $140^{\circ} \mathrm{E}$. The rows of arrowheads in Fig. $8 \mathrm{~B}$ indicate the jet stream axes at $200 \mathrm{hPa}$, with the wind speed exceeding $30 \mathrm{~m} \mathrm{~s}^{-1}$. The zone of largest wind speed more than $40 \mathrm{~m} \mathrm{~s}^{-1}$ elongates along the southern jet axis (the subtropical jet stream). The largescale circulation systems, which are usually associated with the west-east elongating Baiu front, are reasonably simulated for this period.

Figure $8 \mathrm{C}$ shows the time averaged vertical stability $-(\partial \theta e / \partial p)$ in the $925-500 \mathrm{hPa}$ layer simulated for this period. The airs over the southern part of China and ITCZ indicate convectively unstable stratification (negative value of $-\partial \theta e / \partial p$ ), while polar maritime airs exhibit stable stratification. The nearly moist neutral or weak convectively unstable stratification is sustained in the precipitation zone, while stable stratification is maintained in the subtropical anticyclone.

The latitude-time section of simulated precipitation along $135^{\circ} \mathrm{E}$ meridian (Fig. 4A) indicates that the passage of the precipitation system " $\mathrm{D}$ " in 10 June precedes the formation of the rain zone " $\mathrm{Z}$ ". The map of sea-level pressure simulated for 06 UTC 12 June (Fig. 9A) indicates a west-east elongating surface trough, which correspond to the Baiu front (Fig. 9C), extends westward from the depression with the central pressure of $1000 \mathrm{hPa}$. The location of the depression is indicated by $\bigcirc$ at 24 -hour intervals. The $700 \mathrm{hPa}$ geopotential height simulated for 06 UTC 12 June is shown in Fig. 9B. In this map, $\boldsymbol{\Delta}$ indicates 24-hourly location of the $500-\mathrm{hPa}$ vorticity core that is associated with the short-wave trough propagating along 

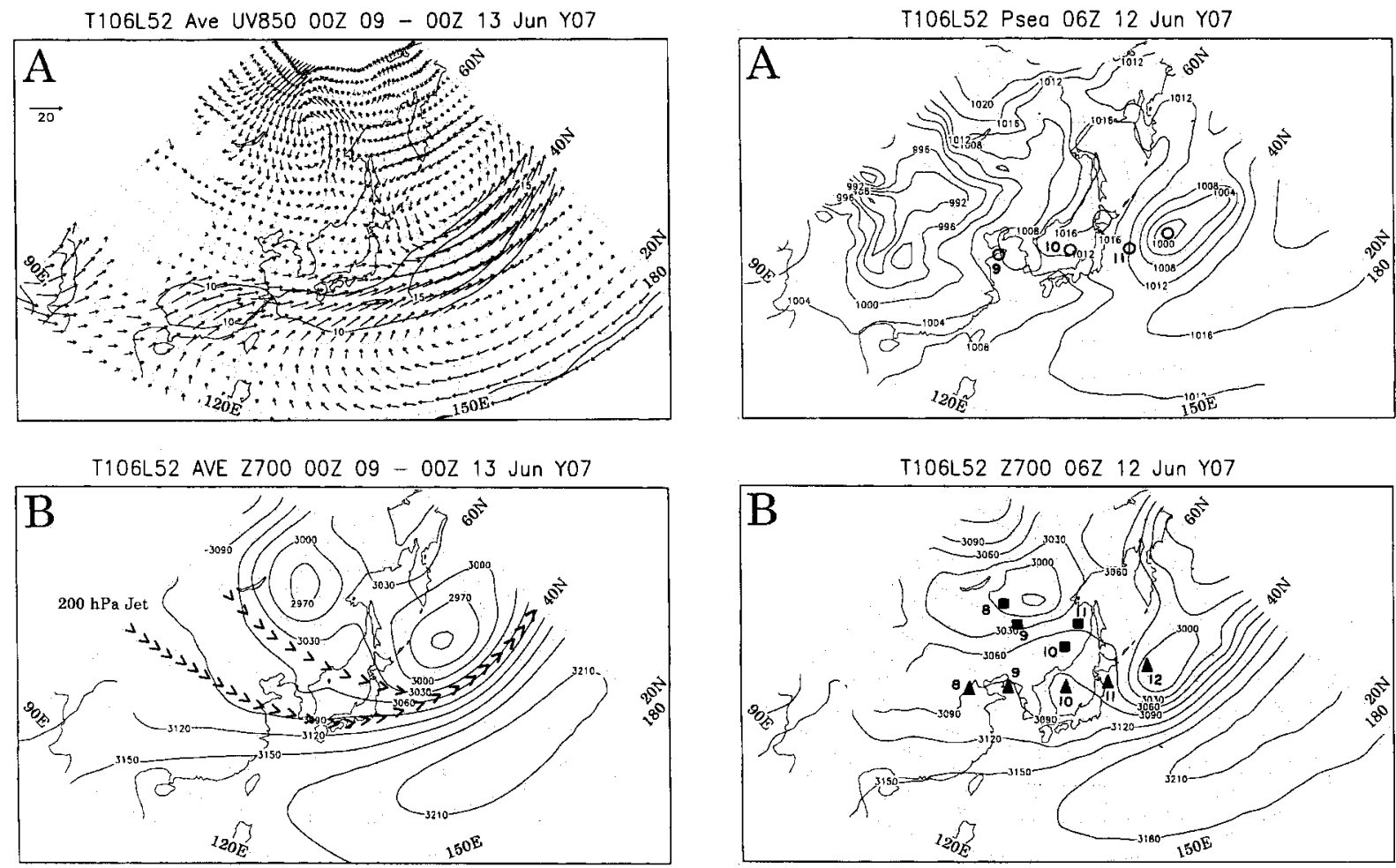

T106L52 sm Ave (EPT5-EPT9)/4.25 00Z 09 - 00213 Jun YO7
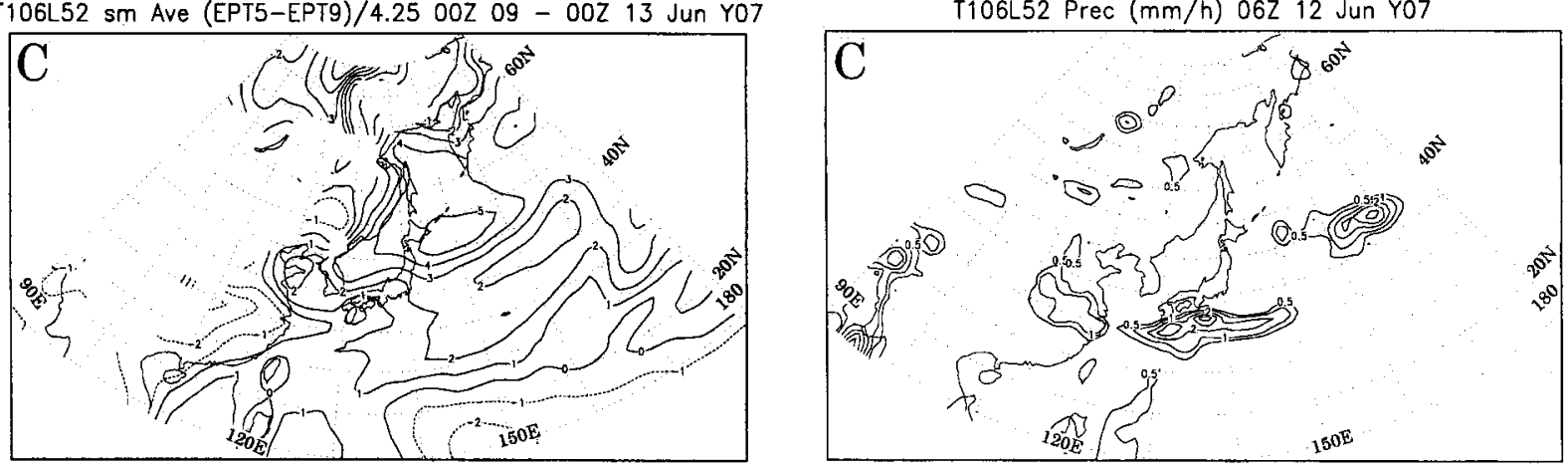

Fig. 8. A: The 5-day averaged wind velocity at $850 \mathrm{hPa}$ (unit: $\mathrm{m} \mathrm{s}^{-1}$ ) for $9-13$ June Y07.

B: The 5-day averaged height at $700 \mathrm{hPa}$ for 9-13 June Y07. Contours are given at $30 \mathrm{~m}$ interval. Rows of the arrowheads shows axis of $200 \mathrm{hPa}$ jet stream with wind speed more than $30 \mathrm{~m} \mathrm{~s}^{-1}$.

C: The 5-day averaged simulated vertical stability $-(\partial \theta e / \partial p)$ in $850-$ $500 \mathrm{hPa}$ layer for 9-13 June Y07. The horizontal smoothing is applied for this map. Isopleths are given at $1 \mathrm{~K}$ $(100 \mathrm{hPa})^{-1}$ intervals.

Fig. 9. A: The sea-level pressure simulated for 06 UTC 12 June Y07. Isobars are given at $4-\mathrm{hPa}$ intervals. The 24hourly location of the cyclone is indicated by $\bigcirc$.

B: The $700-\mathrm{hPa}$ height simulated for 06 UTC 12 June Y07. Contours are given at $30 \mathrm{~m}$ intervals. The 24-hourly location of the $500-\mathrm{hPa}$ vorticity cores, which are associated with northern and southern short-wave troughs, are indicated by $\boldsymbol{\square}$ and $\boldsymbol{\Delta}$, respectively.

$\mathrm{C}$ : The precipitation rate $\left(\mathrm{mm} \mathrm{h}^{-1}\right)$ simulated for 00-06 UTC 12 June. 
the Baiu frontal zone. In this map, $\mathbf{\square}$ indicates the 24-hourly location of the vorticity core at $500 \mathrm{hPa}$, which corresponds to the short-wave trough propagating about the cold low. The vorticity core labeled by $\boldsymbol{\square}$ is not identified at 06 UTC 12.

The depression develops in association with the short-wave trough in the Baiu frontal zone. The central pressure of the depression reaches $992 \mathrm{hPa}$ at 06 UTC 10 June over the Japan Sea (map is not presented), under the influence of the short-wave trough propagating about the cold low. At this time, the pressure depth $\Delta p$ reaches $-8 \mathrm{hPa}$, and the intense precipitation rate of $7 \mathrm{~mm} \mathrm{~h}^{-1}$ is simulated (map is not shown). The maximum of precipitation over the Japan Sea on the averaged precipitation map (Fig. 7A) is accompanied by this depression. Until 18 UTC 11 June, the central pressure of the depression of $996 \mathrm{hPa}$ is sustained, although the pressure depth $\Delta p$ reaches $-12 \mathrm{hPa}$. Then, the depression weakens gradually over the east coast of the Japan Islands and the central pressure of $1000 \mathrm{hPa}$ is simulated at 06 UTC 12 June. The eastward elongation of the low-pressure area from the depression is associated with genesis of the secondary depression (Fig. 13 in Section 7).

The pressure depth $\Delta p$ of this depression $(\sim-10 \mathrm{hPa})$ is significantly smaller than that of the synoptic-scale cyclone studied in Section 5 $(\sim-20 \mathrm{hPa})$. We define the former as the Baiu frontal subsynoptic-scale depression, and the latter as the synoptic-scale cyclone. In some papers, similar subsynoptic-scale depression is defined as the "medium-scale depression" (e.g., Matsumoto et al. 1970) or "subsynoptic-scale depression" (e.g., Ninomiya and Shibagaki 2003).

The Baiu frontal subsynoptic-scale depression does not cause significant cold air outbreak. Yet, the weak cold advection behind the depression sustains the narrow precipitation zone along its trailing portion (Fig. 9C). The passage of a few meso- $\alpha$-scale precipitation systems in the precipitation zone is shown in Fig. 4A.

The streamline and temperature at $925 \mathrm{hPa}$ simulated for 06 UTC 12 June Y07 are shown in Panel A and B in Fig. 10, respectively. In $130-150^{\circ} \mathrm{E}$, the southwesterly/westerly flows along the rim of the Pacific subtropical anti-
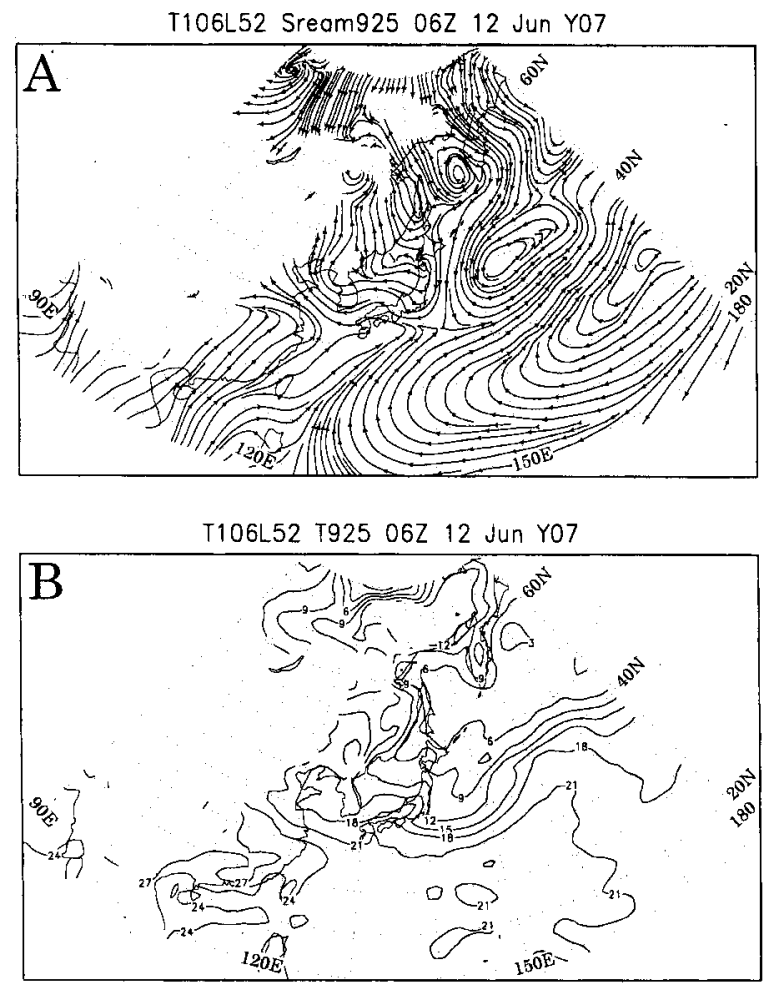

Fig. 10. A: Streamlines of simulated wind velocity at $925 \mathrm{hPa}$ for 06 UTC 12 June Y07.

B: The simulated temperature at $850 \mathrm{hPa}$ for $06 \mathrm{UTC} 12$ June. Isotherms are given at $3^{\circ} \mathrm{C}$.

cyclone and the northerly flows behind the depression sustain the large thermal gradient along the boundary between the tropical maritime airmass and the polar maritime airmass. In $110-120^{\circ} \mathrm{E}$, the thermal gradient between the southern China and the Meiyu frontal zone $\left(\sim 35^{\circ} \mathrm{N}\right)$ is not due to the continent-ocean thermal contrast, but due to the contrast between relatively cool precipitation zone and the warmer surrounding areas. In $120-140^{\circ} \mathrm{E}, 925$ $\mathrm{hPa}$ temperature over the continent is higher than that over the Yellow Sea and the Japan Sea. Therefore, the reversed temperature gradient (north is warmer) appears to the north of the Baiu frontal zone.

The equivalent potential temperature $\theta e$ at $700 \mathrm{hPa}$ simulated for 06 UTC 12 June (Fig. $11 \mathrm{~A})$ indicates a zone of high $\theta e(\sim 340 \mathrm{~K})$ elongating over the precipitation zone. The strong gradient of $\theta e$ is seen in both the northern and 

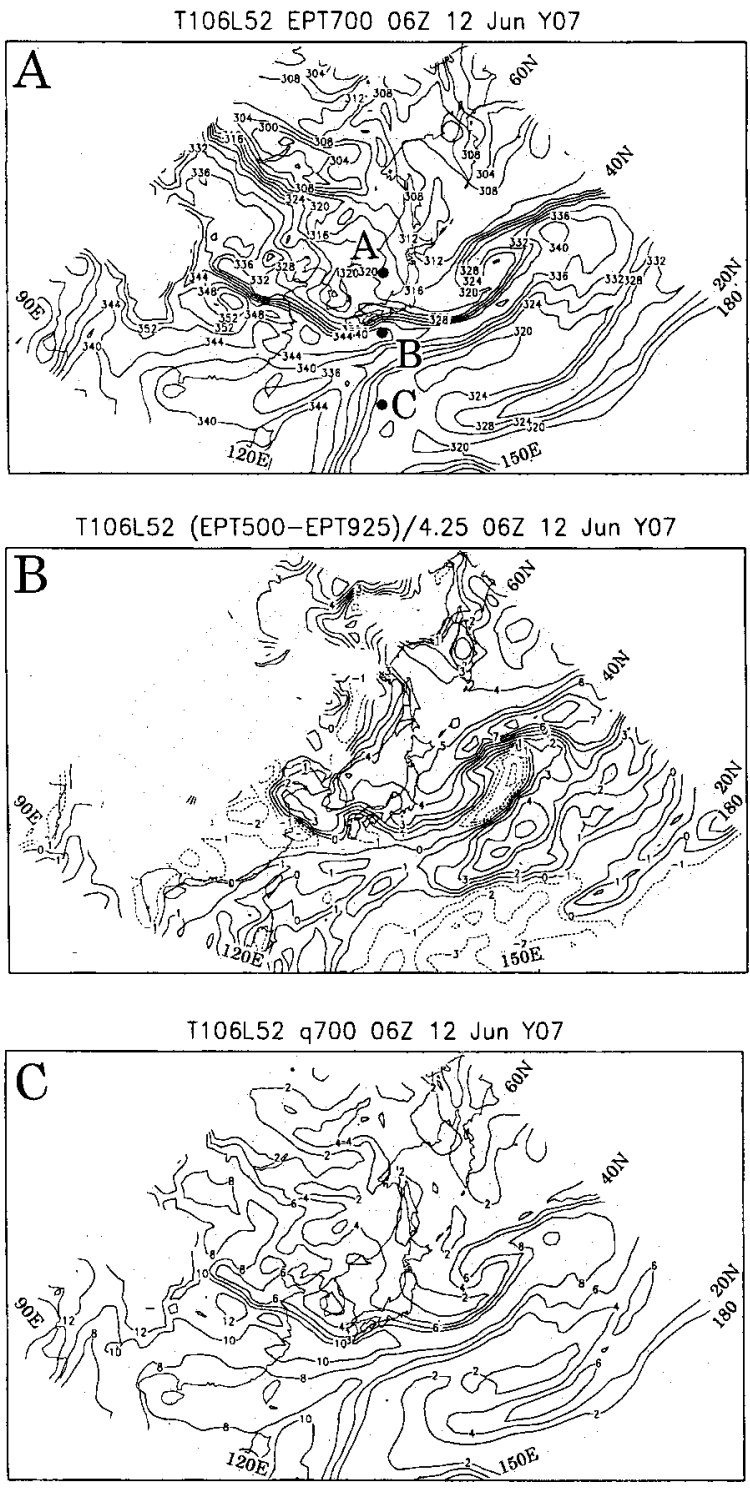

Fig. 11. A: Simulated equivalent potential temperature $\theta e$ at $700 \mathrm{hPa}$ for 06 UTC 12 June of Y07. Isopleths are given at $4 \mathrm{~K}$ intervals. The vertical profiles of $s / c_{p}, h / c_{p}$ and $h^{*} / c_{p}$ at point A, B and $\mathrm{C}$ are presented in Fig. 12.

B: Simulated vertical stability $-(\partial \theta e / \partial p)$ in $925-500 \mathrm{hPa}$ layer for 06 UTC 12 June. The horizontal smoothing is applied for this map. Isopleths are given at $1 \mathrm{~K}(100 \mathrm{hPa})^{-1}$ intervals.

C: Simulated specific humidity at $700 \mathrm{hPa}$ for $06 \mathrm{UTC} 12$ June. Isopleths ate given at $2 \mathrm{~g} \mathrm{~kg}^{-1}$ intervals. the southern side of the precipitation zone. The vertical stability $-(\partial \theta e / \partial p)$ in the $925-500 \mathrm{hPa}$ layer simulated for 06 UTC 12 June is presented in Fig. 11B. The air over the southern parts of China indicates strong convective instability (negative value of $-\partial \theta e / \partial p$ ), while polar maritime air shows stable stratification. The moist neutral or weak convectively unstable stratification is sustained in the precipitation zone, while stable stratification is maintained in the subtropical anticyclone.

The specific humidity at $700 \mathrm{hPa}$ simulated for 06 UTC June (Fig. 11C) shows typical moist tongue, that is, the eastward elongating moist zone over the precipitation zone. Strong gradient of the specific humidity is seen along the north side of the moist zone. The secondary moist zone over the Pacific Ocean, elongating from $\sim 20^{\circ} \mathrm{N} / 145^{\circ} \mathrm{E}$ to $27^{\circ} \mathrm{N} / 180^{\circ} \mathrm{E}$, is the remains of the moist zone discussed in Section 5 .

The vertical stratification in and around the precipitation zone is examined by showing the data at $\sigma$-levels. Vertical distribution $\left(s / c_{p}\right)$, $\left(h / c_{p}\right)$ and $\left(h^{*} / c_{p}\right)$ simulated for 06 UTC 12 June at point A, B and C (see Fig. 11A for location of these points) are presented in Fig. 12. Data at $40^{\circ} \mathrm{N} / 135^{\circ} \mathrm{E}$ (Fig. $12 \mathrm{~A}$; the Japan Sea, to the north of Baiu front) show thick stable layer over the very thin $(\sigma ; 1.00-0.96)$ moist neutral boundary layer. Data at $32^{\circ} \mathrm{N} / 135^{\circ} \mathrm{E}$ (Fig. 12B; within the precipitation zone) indicate nearly moist neutral stratification in the layer below the $\sigma$-level of $\sim 0.65$. The features seen in Fig. 12B are consistent with the observed features in the typical Baiu precipitation zone. Data at $23^{\circ} \mathrm{N} / 135^{\circ} \mathrm{E}$ (Fig. $12 \mathrm{C}$; subtropical Pacific to the south of the precipitation zone) indicate the mixed layer capped by a stable layer, which is due to the subsidence in the subtropical anticyclone.

\section{Meso- $\alpha$-scale precipitation systems in the precipitation zone}

The 6-hourly maps of simulated precipitation rate for the period between 00 UTC 11 and 18 UTC 12 June are presented in Fig. 13. The precipitation system of the frontal subsynopticscale depression (D) itself shows complicated evolution process. At 00 UTC 11 June, the precipitation area extends southeastward from the center of the depression. The southern part of the precipitation area propagates eastward 
T106L52 40N 135E 06212 JUn Y07

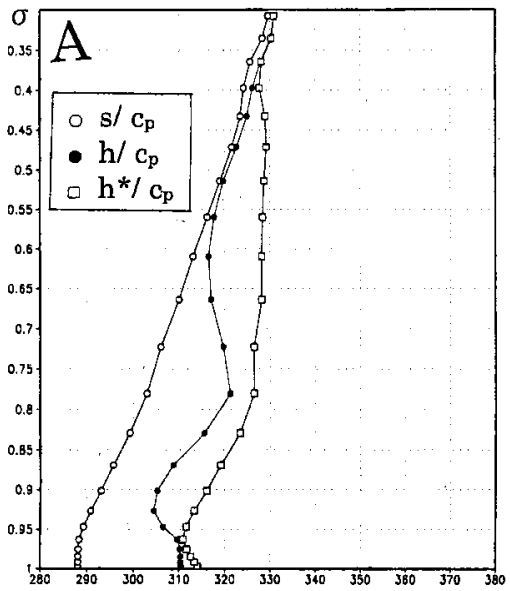

T106L52 32N 135E 06Z 12 Jun Y07

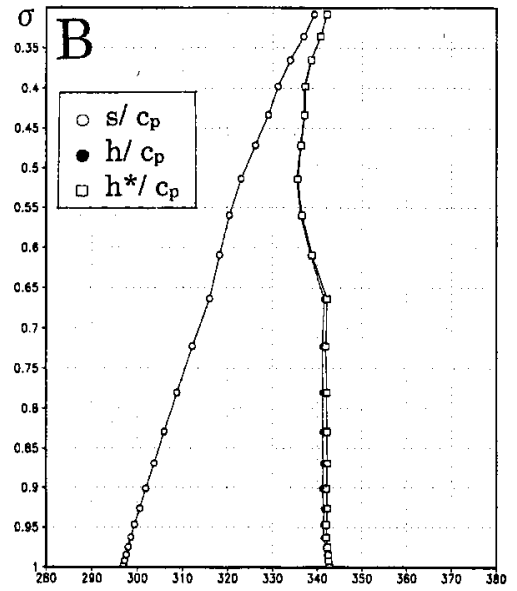

T106L52 23N 135E 06212 Jun Y07

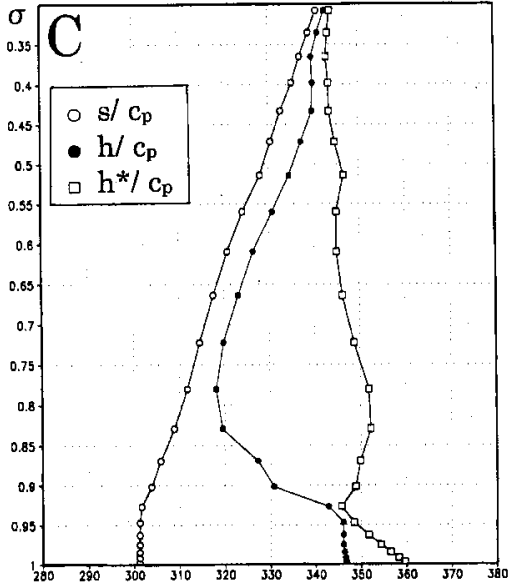

Fig. 12. The vertical distribution of simulated $\left(s / c_{p}\right),\left(h / c_{p}\right)$ and $\left(h^{*} / c_{p}\right)$, in unit of $\mathrm{K}$, for 06 UTC 12 June at point $\mathrm{A}\left(40^{\circ} \mathrm{N}, 135^{\circ} \mathrm{E}\right.$; north to the cloud zone), $\mathrm{B}\left(32^{\circ} \mathrm{N}, 135^{\circ} \mathrm{E}\right.$; within the cloud zone $)$ and $\mathrm{C}\left(23^{\circ} \mathrm{N}, 135^{\circ} \mathrm{E}\right.$; south to the cloud zone). The location of point $\mathrm{A}, \mathrm{B}$ and $\mathrm{C}$ are shown in Fig. $11 \mathrm{~A}$.

with a speed faster than that of the depression, and forms a separated precipitation system $\mathrm{D}^{\prime}$ to the east of $\mathrm{D}$. At the same time, the lowpressure area and the cyclonic vorticity area of the depression extend eastward (Fig. 9A and Fig. 14).

As the subsynoptic-scale depression moves over the Japan Islands, the narrow rain zone is formed along $\sim 30^{\circ} \mathrm{N}$ in the trailing portion of this foregoing depression. In Fig. 13, three meso- $\alpha$-scale precipitation systems, which are labeled by M-1, M-2 and M-3, propagate along the rain zone. From the horizontal spacing between them, and its duration, these systems are reasonably categorized into the meso- $\alpha$ scale.

The 6-hourly maps of simulated vorticity at $925 \mathrm{hPa}$ and $850 \mathrm{hPa}$ for 00 UTC 11-18 UTC 12 June are presented in Figs. 14 and 15, respectively. The meso- $\alpha$-scale precipitation systems M-1 and M-2 are accompanied by respective vorticity maximums at 925 and $850 \mathrm{hPa}$. However, the vorticity maximum corresponding to M-3 is not seen as a separate maximum. Other two mesoscale precipitation systems are seen over China. The simulated rain zone "Z" consists of a few meso- $\alpha$-scale precipitation systems aligned along the rain zone. This feature is consistent with the observed feature of the Baiu cloud/precipitation zone reported by Ni- nomiya and Akiyama (1992) and Ninomiya and Shibagaki (2003).

The precipitation rate, vertical velocity $\omega$ at $600 \mathrm{hPa}$ and total heat source $Q_{1}$ at $600 \mathrm{hPa}$ simulated for 06 UTC 12 June are presented in Panel A, B and C of Fig. 16, respectively. Here, $Q_{1}$ (unit $\mathrm{K} \mathrm{d}^{-1}$ ) is not the apparent heat source, but the total heat source in the model defined by $Q_{1}=d T_{\text {rads }}+d T_{\text {radl }}+d T_{l s c}+d T_{\text {cum }}+d T_{v d f}$. The terms in the right hand of the equation indicate the temperature change due to the process of short-wave radiation, long-wave radiation, large-scale condensation, cumulus convection and vertical diffusion of sensible heat. In the rain zone, the large portion of $Q_{1}$ is due to $d T_{l s c}$ and $d T_{\text {cum }}$. In these maps, the intense precipitation areas coincide with the areas of strong ascending motion and strong total heating. The cores of strong ascending motion with strong heating are simulated over the meso- $\alpha-$ scale precipitation systems M-2 and M-3.

The vorticity at 925,700 and $500 \mathrm{hPa}$ simulated for 06 UTC 12 June are presented in Fig. 17. While the vorticity of the Baiu frontal subsynoptic-scale depression exhibits deep structure reaching to middle troposphere, the vorticity of the meso- $\alpha$-scale precipitation system M-2 is confined within the lower troposphere below $\sim 700 \mathrm{hPa}$. Significant vertical tilt of the vertical vorticity axis is not seen for M- 2 . 
T106L52 Prec $(\mathrm{mm} / \mathrm{h})$

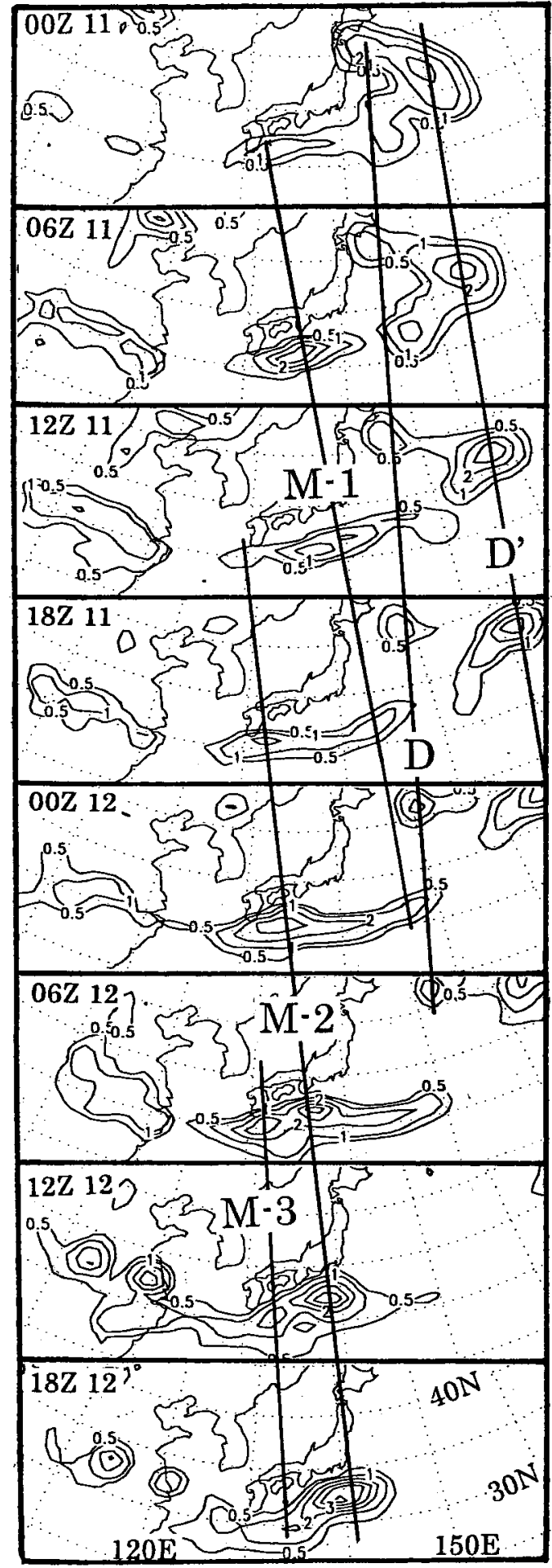

Fig. 13. The 6-hourly maps of simulated precipitation rate for 00 UTC 11-18 UTC 12 June Y07. Isopleths of $0.5,1$, 2, 3, 4 and $5 \mathrm{~mm} \mathrm{~h}^{-1}$ are given. The movement of precipitation systems $\mathrm{D}$, D', M-1, M-2 and M-3 are illustrated.
Although strong cyclonic vorticity are already generated in association with the meso- $\alpha$-scale precipitation system M-2 at 06 UTC 12 , relevant meso- $\alpha$-scale depression is not generated yet (Fig. 9A). A weak meso- $\alpha$-scale depression develops gradually accompanied by the precipitation system M-2 after 12 UTC 12. At 18 UTC 12 , weak meso- $\alpha$-scale depression with the central pressure of $1008 \mathrm{hPa}$, is formed in the rain zone (Fig. 18). At this stage, the pressure depth $\Delta p$ reaches $-4 \mathrm{hPa}$. However, this meso- $\alpha$ scale depression does not develop further. From the cyclonic vorticity confined within the lower troposphere, and small pressure depth $(\Delta p \sim$ $-4 \mathrm{hPa}$ ), this depression is categorized as the Baiu frontal meso- $\alpha$-scale depression. The feature of the simulated meso- $\alpha$-scale depression is consistent with the feature shown in the observational studies (Ninomiya and Akiyama 1992; Ninomiya and Shibagaki 2003), and in a theoretical study of the baroclinic disturbance in the moist neutral airs (Tokioka 1973).

The simulated process indicates the important role of the preceding subsynoptic-scale depression on the formation of the narrow zone of nearly moist neutral stratification with weak baroclinicity, which provides favorable condition for the successive generation of meso- $\alpha$ scale precipitation systems.

At the end of this section, the feature around $160^{\circ} \mathrm{E}$ is briefly noted. Features of precipitation systems at $160^{\circ} \mathrm{E}$ (Fig. 4B) are significantly different from these at $135^{\circ} \mathrm{E}$ (Fig. 4A). The larger precipitation systems "S" or "D", which are accompanied by the synoptic-scale cyclone or the subsynoptic-scale depression, propagate from $135^{\circ} \mathrm{E}$ to $160^{\circ} \mathrm{E}$ with the phase speed of $\sim 1000 \mathrm{~km} \mathrm{~d}^{-1}$. Meanwhile the meso- $\alpha$-scale precipitation systems do not reach to $160^{\circ} \mathrm{E}$. The following large-scale conditions will explain why the meso- $\alpha$-scale precipitation systems are not sustained over the Pacific. First, the stable stratification over the Pacific (Fig. $8 \mathrm{C}$ ) is an unfavorable condition for the maintenance of the meso- $\alpha$-scale precipitation systems. Second, the large baroclinity in the lower troposphere over the Pacific (Fig. 7C) is a favorable condition for the development of synoptic-scale cyclone and the subsynopticscale depression. The meso- $\alpha$-scale systems are suppressed by the development of these larger circulation systems. 
T106L52 smth ROT925

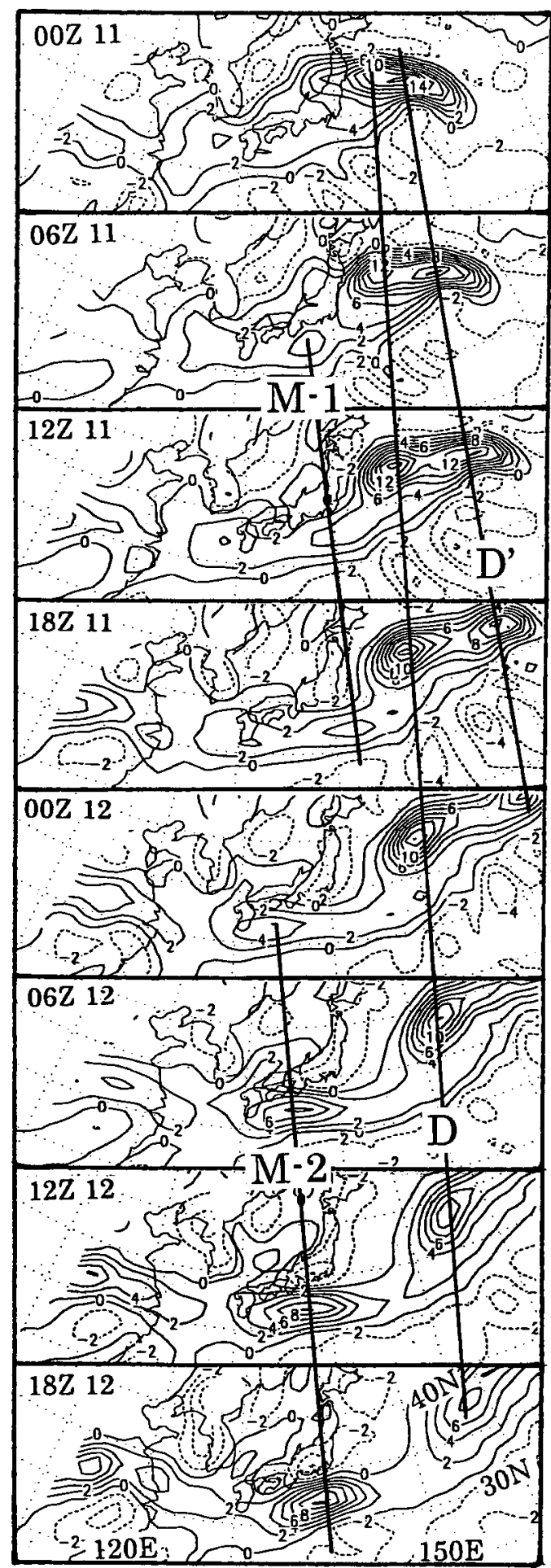

\section{Disappearance of the Baiu precipitation zone in July}

The synoptic- and meso- $\alpha$-scale variations of the Baiu front are properly simulated by T106L52, for 1-20 June Y07. However, the result of present simulation indicates the faster seasonal march as compared with the real seasonal march. While the climatological peak period of the Baiu precipitation appears in 20-30 June (Ninomiya and Murakami 1987), the simulated peak period is seen in the earlier half of June Y07. Moreover, in the present simulation, the Baiu frontal rain zone begins to shift northward about the end of June Y07. The Baiu frontal rain zone is not seen over the Japan Islands in 1-15 July Y07 (Fig. 19A). Instead, a horseshoe shaped precipitation zone appears around the anticyclone which extending over $\sim 37^{\circ} \mathrm{N}$ (Fig. 19B). The large precipitation over $\sim 23^{\circ} \mathrm{N}$ and $\sim 145^{\circ} \mathrm{E}$ is caused by the tropical cyclones generated in the model.

The Tibetan anticyclone in the middle and upper troposphere, and an anticyclonic zone of barotropic structure over $\sim 37^{\circ} \mathrm{N}$, which are the typical large-scale circulations usually observed in August, is maintained even in the earlier half of July Y07 (Figs. 19B and 19C). Simultaneously, the jet stream at $200 \mathrm{hPa}$ weakens significantly (figure is not shown). Similar faster seasonal march is also found in the simulation for Y06.

Kawatani and Takahashi (2003) also reported a similar earlier end of the Baiu in the simulation study using T106L60. Further, they demonstrated that the earlier end of Baiu was also simulated when the Arakawa-Schubert cumulus convection scheme in their model was replaced by Kuo scheme or moist convective adjustment scheme.

The rapid intensification of the Tibetan anticyclone in the upper troposphere (figure is not

Fig. 14. The 6-hourly maps of simulated vorticity at $925 \mathrm{hPa}$ for 00 UTC 11-18 UTC 12 June Y07. The horizontal smoothing is applied for this map. Isopleths are given at $2 \times 10^{-5} \mathrm{~s}^{-1}$ interval. The movement of the vorticity cores associated with the precipitation systems D, D', M-1 and M-2 are illustrated. 


\section{T106L52 smth ROT850}

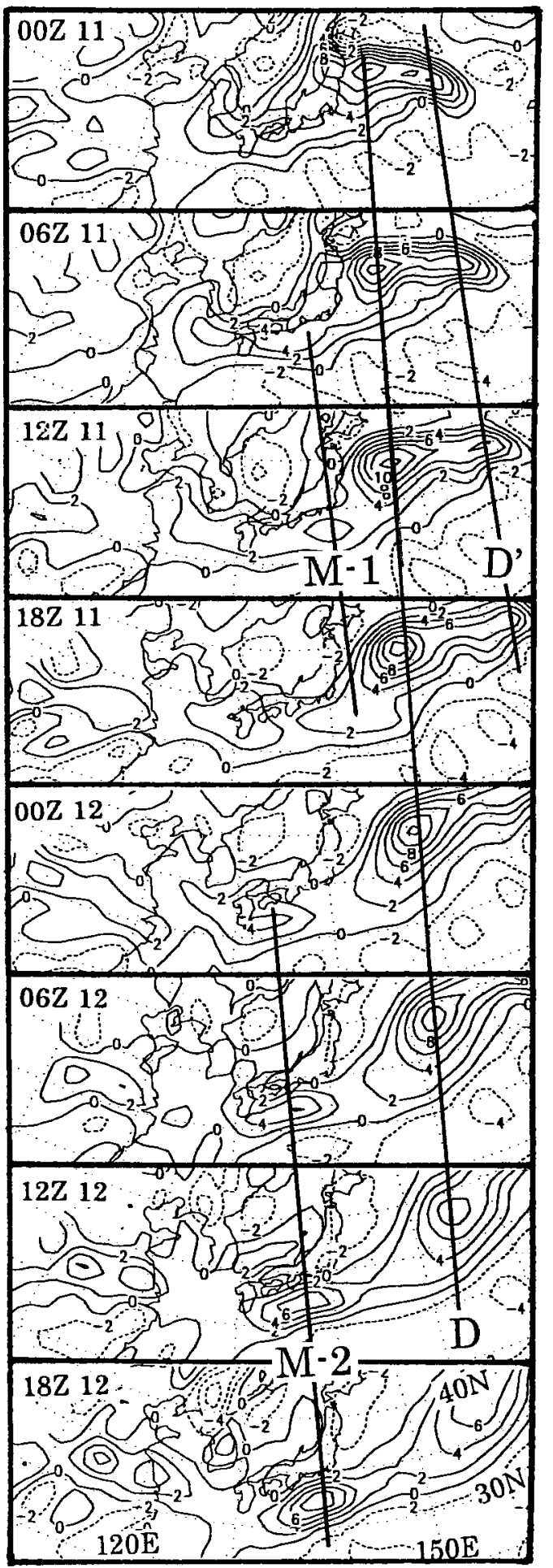

presented) may be one of the factors related to the earlier end of the Baiu rain season in the model. The influence of the cumulus convections over the tropical Pacific Ocean is also one of the factors related to the variation of the Pacific subtropical anticyclone. Nitta (1987) pointed out in his observational study that the stationary Rossby wave propagation from the western Pacific convective heating region has strong influence on the intensification of the subtropical anticyclone in summer. Enomoto et al. (2003) have proposed a hypothesis that the barotropic ridge over Japan is intensified in association with the propagation of stationary Rossby wave along the Asian upper jet stream. The studies on the intensification of the barotropic ridge over Japan in summer, in both real and model atmosphere, are needed to clarify the reason of the earlier termination of the Baiu period in the present simulation. One of the present authors discusses this problem in real atmosphere in a separate article (Enomoto 2003). Of course, the fundamental process that drives the general circulation is the differential radiative heating. Giorgi et al. (1998) discussed the influences of the radiative process and surface process on the seasonal march of the East Asia rainy season in a regional model simulation. However, this problem is not discussed in the present paper.

\section{Concluding remarks}

In this article, we study features of the Meiyu-Baiu front and the associated precipitation systems simulated in the seasonally varying climatological SST run by the T102L52 model, which is the high-resolution version of CCSR/NIES T42L20.

The Baiu front is properly reproduced for 120 June Y07. In this "Baiu phase", the largescale circulation systems, such as the upper

Fig. 15. The 6-hourly maps of simulated vorticity at $850 \mathrm{hPa}$ for 00 UTC 11-18 UTC 12 June Y07. The horizontal smoothing is applied for this map. Isopleths are given at $2 \times 10^{-5} \mathrm{~s}^{-1}$ intervals. The movement of the vorticity cores associated with the precipitation systems D, D', M-1 and M-2 are illustrated. 

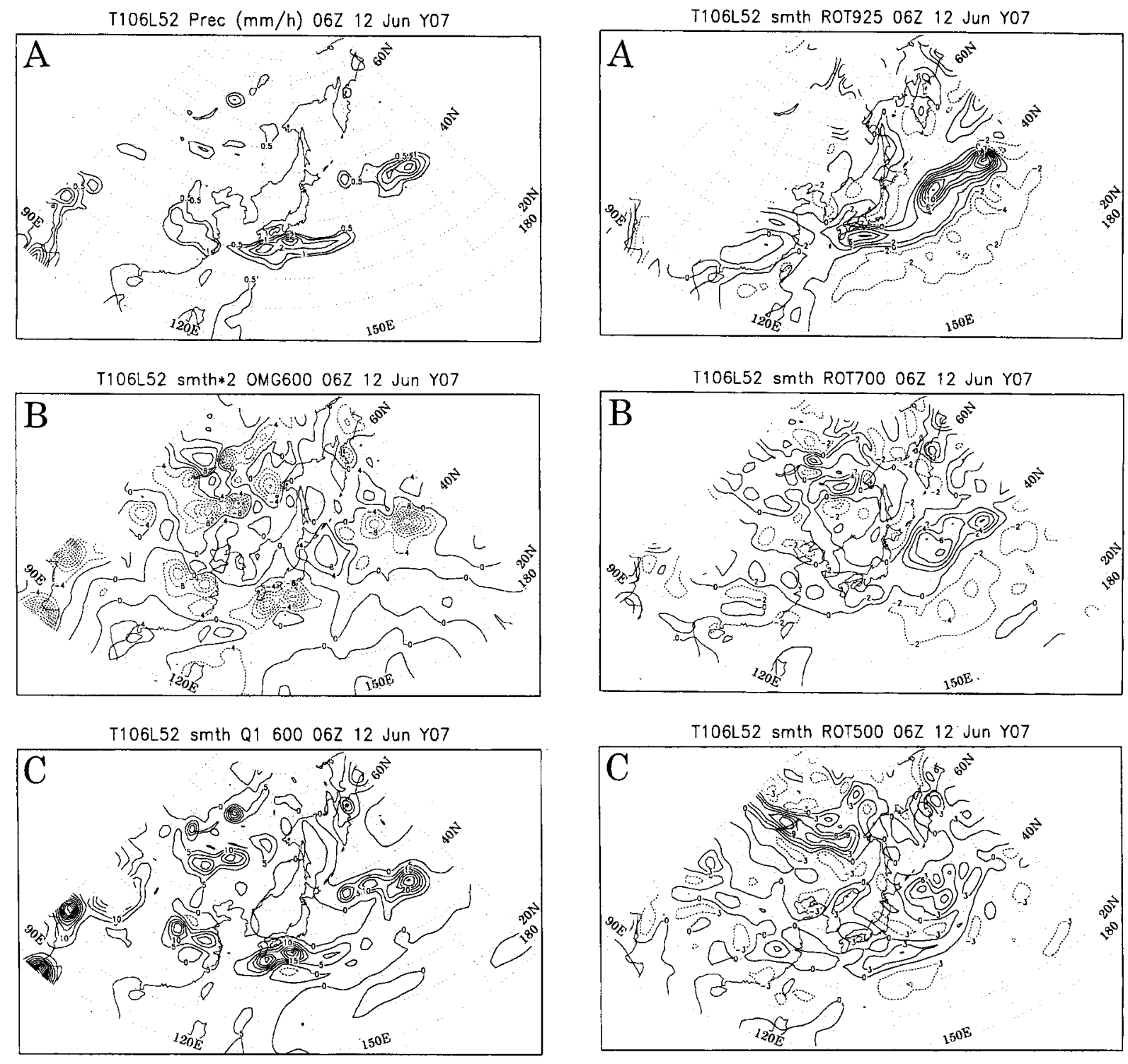

Fig. 16. A: The precipitation rate simulated for 06 UTC 12 June Y07. Isopleths of $0.5,1,2,3,4$ and $5 \mathrm{~mm} \mathrm{~h}^{-1}$ are given.

B: Vertical velocity $\omega$ at $600 \mathrm{hPa}$ simulated for 06 UTC 12 June. The horizontal smoothing is applied. Isopleths are given at $4 \mathrm{hPa} \mathrm{h}^{-1}$ intervals.

C: Heat source $Q_{1}$ at $600 \mathrm{hPa}$ simulated for 06 UTC 12 June. The horizontal smoothing is applied on this map. Isopleths are given at $5 \mathrm{~K} \mathrm{~d}^{-1}$ intervals.

Fig. 17. A: The vorticity at $925 \mathrm{hPa}$ simulated for 06 UTC 12 June Y07. The horizontal smoothing is applied on this map. Isopleths are given at $2 \times 10^{-5} \mathrm{~s}^{-1}$ intervals.

$\mathrm{B}$ : The vorticity at $700 \mathrm{hPa}$ simulated for 06 UTC 12 June Y07. The horizontal smoothing is applied on this map. Isopleths are given at $2 \times 10^{-5} \mathrm{~s}^{-1}$ intervals.

$\mathrm{C}$ : The vorticity at $500 \mathrm{hPa}$ simulated for 06 UTC 12 June Y07. The horizontal smoothing is applied on this map. Isopleths are given at $3 \times 10^{-5} \mathrm{~s}^{-1}$ intervals. 


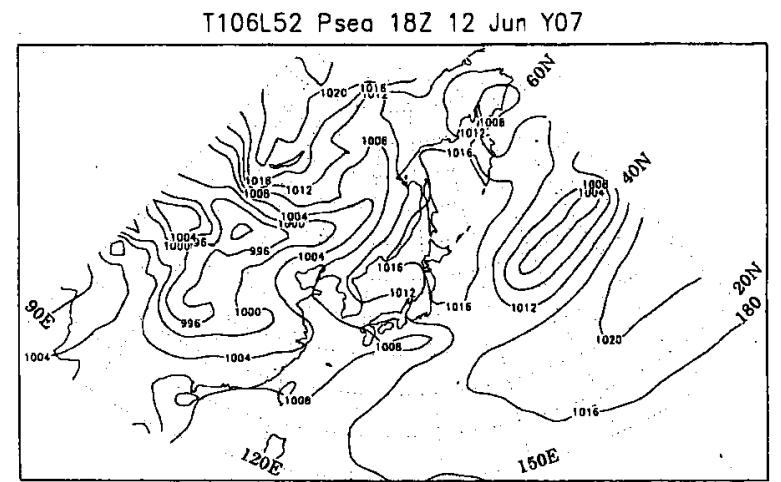

Fig. 18. The sea-level pressure simulated for 18 UTC 12 June Y07. Isobars are given at $4-\mathrm{hPa}$ intervals.

cold lows and blocking ridge in the northern latitudes, westward extending Pacific subtropical anticyclone, the subtropical jet stream, and monsoon westerly are reasonably maintained. Under this large-scale condition, a realistic Meiyu-Baiu front is formed and sustained in the model. The structure of the Meiyu-Baiu front is consistent with that found in observational studies.

During this Baiu phase, the simulated Baiu front indicates synoptic- and meso- $\alpha$-scale variations in association with the changes of largescale circulations. When, a synoptic-scale cyclone develops in the vicinity of the Japan Islands, the Baiu frontal rain zone indicates a "wavy pattern" with large south-north amplitude.

Meanwhile, when the Pacific subtropical anticyclone extends westward, and the westerly waves in the middle latitudes are inactive, the subsynoptic-scale Baiu frontal depression is generated. The west-east elongating Baiu precipitation zone is sustained along the trailing portion of the depression. The simulated front exhibits feature of a train of precipitation systems with length of $\sim 2000 \mathrm{~km}$, which is recognized as "precipitation system family". A family consists of a preceding sub-synoptic-scale precipitation system associated with the depression, and a few meso- $\alpha$-scale precipitation systems aligning along the trailing portion of the preceding depression. These meso- $\alpha$-scale systems are accompanied by the respective vorticity maximum in the lower troposphere. The
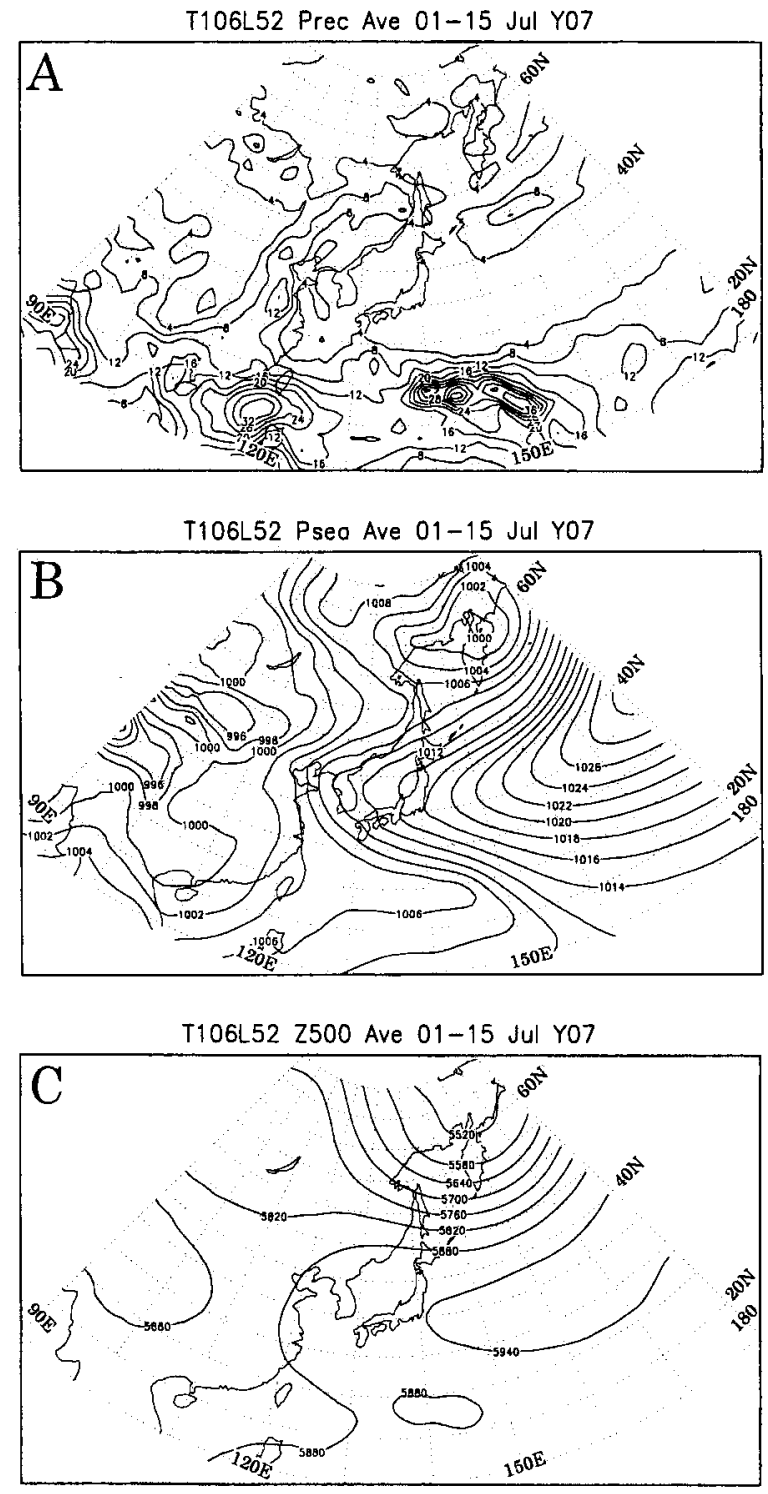

Fig. 19. A: Averaged precipitation simulated for 1-15 July Y07.

B: Averaged surface pressure simulated for 1-15 July Y07. The isobars are given at $4 \mathrm{hPa}$ intervals.

C: Averaged 500-hPa height simulated for 1-15 July Y07. The height contours are given at $60 \mathrm{~m}$ intervals.

"precipitation system family" is formed within the area between $115^{\circ} \mathrm{E}$ and $150^{\circ} \mathrm{E}$, where the weak baroclinity and nearly moist neutral stratification are maintained in the Baiu frontal zone. The simulated features are consistent 
with the results of the observational studies (e.g., Ninomiya 2000; Ninomiya and Akiyama 1992; Ninomiya and Shibagaki 2003).

The basic features of the Meiyu-Baiu frontal precipitation zone, including the "precipitation system family" are reasonably reproduced by present T106L52, without special tuning of the parameterization for the Baiu frontal rainfalls, when large- and synoptic-scale circulation systems over the East Asia and western Pacific are properly simulated. This indicates that production of reasonable large- and synoptic-scale systems is crucially important to simulate Baiu frontal precipitation systems in the AGCM.

Of course, the resolution of T106L52 (Gaussian grid of $\sim 1.1^{\circ}$ ) is not enough to simulate the detailed features of the Baiu front, frontal depressions, and meso- $\alpha$-scale precipitation systems. At present, some simulation studies using T1279L96 are carried out (e.g., Enomoto 2002). Detailed comparison among the results from various models and observations are needed to prove the validity of the simulations, and to further our understanding about Baiu precipitation systems.

The present experiment, similar to that by Kawatani and Takahashi (2003), simulate the earlier end of the Baiu rainy season at the beginning of July. This rapid seasonal march is closely related to the formation of a barotropic anticyclone zone over the Japan Islands, as described in Section 8. Unfortunately, the key to ameliorate the model, in regard to the earlier end of Baiu, has not yet been obtained, since dynamical processes related to formation of the barotropic anticyclone, in both the numerical model, and the real atmosphere, cannot be studied in the present report.

Nevertheless, the present paper has significant meaning, since it is the first attempt to study the Meiyu-Baiu precipitation systems in the AGCM in detailed comparison with features found in observational studies.

\section{Acknowledgement}

The authors would like to express their thanks to the joint climate modeling group of the Center for Climate System Research of the University of Tokyo, the National Institute of Environmental Sciences, and the Frontier Research System for Global Change, for permitting the use of T106L52 for this study. We also thank two anonymous reviewers for their valuable comments and advise.

\section{References}

Akiyama, T., 1973: The large-scale aspects of the characteristic features of the Baiu front. Pap. Meteor. Geophy., 24, 151-188. , 1989: Large, synoptic and meso scale variations of the Baiu front, during July 1982. Part 1: Cloud features. J. Meteor. Soc. Japan, 67, $57-81$.

, 1990: Large, synoptic and meso scale variations of the Baiu front, during July 1982. Part 2: Frontal structure and disturbances. J. $\mathrm{Me}$ teor. Soc. Japan, 68, 557-574.

Ding, Y.-H., 1991: Monsoon over China. Kluwer Academic Pub. 419 pp.

Enomoto, T., 2002: Representation of the Baiu (Meiyu) frontal zone in a T1279L96 model on the Earth Simulator. Proceeding of International Conference on Mesoscale Convective Systems and Heavy Rainfall/Snowfall in East Asia, 29-31 October 2002, Tokyo, Japan. 510514.

2003: Interannual variability of the Bonin high associated with the propagation of Rossby waves along the Asian jet. Submitted to J. Meteor. Soc. Japan.

— B.J. Hoskins, and Y. Matsuda, 2003: The formation mechanism of the Bonin high in $\mathrm{Au}$ gust. Quart. J. R. Meteor. Soc., 129, 157-178.

Georgi, F., Y. Huang, K. Nishizawa, and C. Fu, 1999: A seasonal cycle simulated over eastern Asia and its sensitivity to radiative transfer and surface processes. J. Geophys, Res., 104, 64036423.

Kar, S.C., M. Sugi, and N. Sato, 1996: Simulation of the Indian summer monsoon and its variability using the JMA global model. Papers Meteor. Geophy, 47, 65-101.

Kawatani, Y. and M. Takahashi, 2003: Simulation of the Baiu front in a high resolution AGCM. $J$. Meteor. Soc. Japan, 81, 113-129.

Matsumoto, S., S. Yoshizumi, and M. Takeuchi, 1970: On the structure of the Baiu front and associated intermediate-scale disturbances in the lower atmosphere. J. Meteor. Soc. Japan, 48, 479-491.

Ninomiya, K., 1984: Characteristics of the Baiu front as a predominant subtropical front in the summer northern hemisphere. J. Meteor. Soc. Japan, 62, 880-894.

, 2000: Large- and meso- $\alpha$-scale characteristics of Meiyu-Baiu front associated with intense rainfalls in 1-10 July 1991. J. Meteor. Soc. Japan, 78, 141-157. 
2001: Large $\lambda$-shaped cloud zone formed around July 6, 1991 with pole-ward moisture transport from intense rainfall area in MeiyuBaiu front. J. Meteor. Soc. Japan, 79, 805-813. and T. Akiyama, 1992: Multi-scale features of Baiu, the summer monsoon over Japan and the East Asia. J. Meteor. Soc. Japan, 70, 467495 .

and T. Murakami, 1987: The early summer rainy season (Baiu) over Japan. Monsoon $\mathrm{Me}$ teorology, Edit. P.-C. Chang and T.N. Krishnamurti, Oxford Univ. Press, 93-121.

and H. Muraki, 1986: Large-scale circulation over the East Asia during Baiu period of 1979. J. Meteor. Soc. Japan, 64, 409-429.

and Y. Shibagaki, 2003: Cloud system families in the Meiyu-Baiu Front observed during 1-10 July 1991. J. Meteor. Soc. Japan, 81, 193-209.

, T. Nishimura, W. Ohfuchi, T. Suzuki, and S. Matsumura, 2002: Features of the Baiu Front simulated in an AGCM (T42L52). J. Meteor. Soc. Japan, 80, 697-716.

Nitta, T., 1987: Convective activities in the tropical western Pacific and their impact on the North- ern Hemisphere summer circulation. J. Meteor. Soc. Japan, 65, 373-390.

Numaguti, A., M. Takahashi, T. Nakajima, and A. Sumi, 1997: Description of CCSR/NIES atmospheric general circulation model. CGER Super Computer Monograph Report, No. 3, 1-48, Center for Global Environmental Research, National Institute for Environmental Studies.

Sugi, M., R. Kawamura, and N. Sato, 1995: The climate simulated by the global model. Part 1: Global features. Report of the National Research Institute for Earth Sciences and Disaster Prevention, No. 54, 155-180.

Tao, S. and L. Chen, 1987: A review of recent research on the East Asia summer monsoon over China. Monsoon Meteorology, Edit. P.-C. Chang and T.N. Krishnamurti, Oxford Univ. Press, 50-92.

Tokioka, T., 1973: A stability study of medium-scale disturbances with inclusion of convective effects. J. Meteor. Soc. Japan, 51, 1-10.

Yoshikane, T., F. Kimura, and S. Emori, 2001: Numerical study on the Baiu front generated by heating contrast between land ocean. J. Meteor. Soc. Japan, 79, 671-686. 